\title{
El viaje: una crítica al concepto de "no
}

lugares"

\author{
Maxi Korstanje \\ Universidad Católica Argentina \\ MKorstanje@hertzargentina.com.ar
}

\section{Resumen}

Una de las motivaciones que me llevaron a iniciar esta investigación fue comprender el concepto de "no datos empíricos claros y llegar a una conclusión propia sobre el tema.

Ahora bien para eso hay que servirse de dos elementos analíticos distintivos pero similares, ellos son la migración y su reverso el turismo. A través de diversos indicadores recogidos mediante testimonios de argentinos que han tenido que emigrar al exterior, como datos de reclamos y demandas de turistas, pasando también por el análisis de parte la normativa vigente en el turismo es que he podido confirmar que la tesis de los no lugares es falsa, vacía y ambigua. Sin embargo, es usada en los más distinguidos ámbitos académicos, en la literatura periodística, en la arquitectura y hasta en la antropología social misma.

Palabras clave: No Lugares; Migración; Turismo

\section{Abstract}

One of the motivations that led me to initiating this research was to understand the concept of "nonplaces" in Marc Augé, then to confirm it against empirical clear information and to come to a proper conclusion on the topic. For that it is necessary to use two analytical, distinctive but similar, elements, these are migration and its opposite tourism. Throughout of diverse indicators gathered by means of Argentinians' testimonies that have had to emigrate abroad, as information of claims and tourists' lawsuits as well as for some regulations and procedures in tourism. Afterwards analysing these, I have confirmed that the thesis of nonplaces is false, empty and ambiguous. Nevertheless, it is used in the most distinguished academic areas, in journalistic literature, in architecture and even in some social anthropology works.

Keywords: Non-Places, Migration, Tourism

En la actualidad, está de moda hablar de los "no lugares". En referencia a este término, se considera un "no lugar", a un espacio de tránsito en el cual la identidad del viajante se distorsiona. Un lugar que no es lugar sino su negación más acérrima. Ejemplo de estos sitios vemos todos los días, en los aeropuertos, las estaciones de tren o las estaciones de subte. En definitiva, "el no lugar" parece dar a entender un espacio de temporalidad presente. Sin embargo, la pregunta que muchos deben estar haciéndose es ¿qué es precisamente un no lugar?

El creador de este término fue, el filósofo francés, Marc Augé. En el año 1992 escribió Non-lieux. Introduction a une antropología de la submodernité, cuya edición en español se tradujo como Los No Lugares, espacios de anonimato. Para el autor "si un lugar puede definirse como lugar de identidad, relacional e histórico, un espacio que no puede definirse ni como espacio de identidad ni como relacional ni como histórico, definirá un no lugar". (Augé M, 1996:83) ${ }^{1}$

\footnotetext{
${ }^{1}$ Es curioso que Augé no defina claramente en sus veinte primeras páginas el concepto de no lugar, sino recién en la página cuarenta. En español Submodernité fue traducido como Sobremodernidad.
} 
La intención original de nuestro ensayo es realizar una mirada crítica sobre el concepto de "no lugar" y las diferentes limitaciones para adaptarla al mundo de los hechos empíricos, sobre todo en campos de la industria de los viajes y el turismo. La primera pregunta que no se comprende bien es ¿donde se encuentra físicamente un no lugar?, si precisamente como su nombre lo indica, el concepto es una negación del lugar mismo. ${ }^{2}$

La obra de Augé se divide en seis partes bien definidas: un prólogo y 3 capítulos, más un epílogo y las referencias bibliográficas. Uno por uno iremos desmenuzando el contenido de cada capítulo y sometiendo su tesis al rigor de los hechos fácticos que día a día se observan en la vida social.

\section{OBSERVAR LA REALIDAD SOCIAL}

Al tocar el tema de cómo distinguir y estudiar la realidad social, John Searle señala "podemos ver claramente la distinción entre distinciones, si reflexionamos sobre el hecho de que podemos formular enunciados epistemicamente subjetivos sobre entidades que son antológicamente objetivas, y análogamente, podemos formular enunciados epistemicamente objetivos sobre entidades que son antológicamente subjetivos. Por ejemplo, el monte Everest es más bello que el monte Withney es un enunciado acerca de entidades antológicamente objetivas, pero hace un juicio subjetivo sobre ellas" (Searle J, 1997:28). ¿Dentro de que clasificación entraría un no lugar?, y como ¿observar un no lugar?

Para Augé la cosa parece ser mucho más fácil. Comienza su prólogo describiendo el embarque de Juan Perez antes de comenzar un viaje a París por la empresa Air France. Dice el autor "el hombre se presentó con anticipación al control policial para hacer algunas compras en el duty free ... saboreaba la impresión de libertad que la daban a la vez el hecho de haberse liberado del equipaje y, más íntimamente, la certeza de que sólo había que esperar el desarrollo de los acontecimientos ahora que se había puesto en regla, que ya había guardado la tarjeta de embarque y había declarado su identidad ... (Augé, 1997:10) Una vez en el avión leyó algunas revistas, reviso la nueva tecnología de su asiento, y se preparó para el despegue. Se abrochó el cinturón, y sintonizó el canal 5 para disfrutar de un concierto en do mayor de Joseph Hayden. Y dice el autor "estaría por fin solo". (Ibid, 13).

En su primer capítulo, el autor hace una distinción antropológica entre lo lejano y lo cercano. Esa distinción lo lleva a los orígenes de la disciplina misma, cuando lo que se observaba era lo lejano o "el allá", pero desde el punto de vista de lo cercano. ${ }^{3}$ Su primer pregunta plantea entonces, ¿si es posible que los etnólogos europeos estén aptos para analizar su propia sociedad?, pero su segunda es más abarcativa. Augé se cuestiona directamente; ¿los hechos y las instituciones del mundo actual puede ser analizado desde un punto de vista antropológico? Entonces, responde inmediatamente a su cuestionamiento "no es Europa lo que está en cuestión sino la contemporaneidad en tanto tal, bajo

\footnotetext{
${ }^{2}$ La segunda gran contradicción del autor, es darle, como veremos más adelante ubicación geográfica a un concepto teórico que según él "no es".

${ }^{3}$ El autor, intenta seguir una cronología histórica del surgimiento de la antropología como ciencia. "detrás de la cuestión de la etnología de lo cercano se perfila, en efecto, una doble pregunta. La primera consiste en saber si, en su estado actual, la etnología de Europa puede pretender el mismo grado de refinamiento, de complejidad, de conceptualización que la etnología de las sociedades lejanas" (Pág. 18). Se ponen de vista dos perspectivas, la observación del otro que es diferente a mí, o la observación del otro similar.
} 
los aspectos más agresivos o más molestos de la actualidad más actual". (ibid: 19). Cita el estructuralismo de Levy Strauss, cuando tiene que hacer referencia a la forma de aislar las unidades de estudio. ¿Cuál es el objeto de la antropología entonces? ‘¿Lo interno o lo externo? Si bien, él no lo enuncia de esa manera, esa es la pregunta que subyace en todo su cuestionamiento y su disociación entre la historia y la antropología. ${ }^{4} \mathrm{El}$ autor, denomina al método "lo previo al objeto", y supongamos por un momento que su apreciación sea correcta. La cuestión principal en Augé es encontrar nuevos objetos de investigación para tratar "al otro" y que trasciendan la limitante del tiempo. La siguiente fase ejemplifica muy bien hacia que rumbo dirige su mirada "es suficiente saber de qué se habla y nos basta aquí comprobar que, cualquiera que sea el nivel al que se aplique investigación antropológica, siempre tiene por objeto interpretar la interpretación que otros hacen de la categoría del otro en los diferentes niveles en que se sitúan su lugar e imponen su necesidad ... no es la antropología la que, cansada de terrenos exóticos, se vuelve hacia horizontes más familiares, a riesgo de perder allí su continuidad, como teme Louis Dummont, sino el mundo contemporáneo mismo el que, por el hecho de sus transformaciones aceleradas, atrae la mirada antropológica, es decir, una reflexión renovada y metódica sobre la categoría de la alteridad" (ibid, 30).

De este razonamiento surge su concepto de tiempo y la relación que éste tiene con la identidad. En pocas palabras, la superabundancia de hechos presentes se deriva la dificultad de poder darle un sentido a nuestro pasado más inminente. La causa, principal, de esa saturación de sentido del presente corresponde a la sobre modernidad, como Augé la denomina. El segundo aspecto a tener en cuenta, es el espacio; los medios de transporte y de comunicación nos llevan en forma súbita a las realidades más lejanas. Una producción de imaginarios simbólicos que llevan a lo que el autor llama "la superabundancia espacia del presente". $Y$ es precisamente aquí donde toma la definición de Mauss en su tratamiento de lugar y recalca "Ios no lugares son tanto las instalaciones necesarias para la circulación acelerada de personas y bienes (vías rápidas, empalmes de rutas, aeropuertos) como los medios de transporte mismos o los grandes centros comerciales, o también los campos de tránsito prolongado donde se estacionan los refugiados del planeta" (ibid: 41). Quiere significar, en otras palabras, lugares sin historia común e identidad construidas colectivamente o quien sabe porque fuerza que asociada a la modernidad sin espacio y sin tiempo. El tercer elemento, es la exacerbación del ego provocado por un universo sin territorialidad. Este concepto presupone que el ego individual está asociado a los límites tempo espaciales, lo cual es un concepto muy discutible desde cualquier abordaje. Por ese motivo, propone el filósofo francés, su problema "Así se le plantea hoy en términos nuevos a los antropólogos un problema que suscita las mismas dificultades que enfrentó Mauss y, después de él, el conjunto de la corriente culturalista: ¿Cómo pensar y situar al individuo? (ibid: 44). ${ }^{5}$ Sin embargo, la construcción del objeto antropológico que Augé hace tiene ciertas limitaciones.

En primer lugar, su retórica forma de escribir hace al texto inicial sumamente complejo y ambiguo cuando tiene que precisar los motivos por cuales él cree que la antropología del siglo XXI está autorizada a observar las propias sociedades. En segundo, en ningún momento da una definición

\footnotetext{
4 "el etnólogo de campo, si trabaja a conciencia, tiene siempre la posibilidad de ir a ver un poco más lejos si aquello que ha creído poder observar al comienzo sigue siendo válido. Es la ventaja de trabajar sobre el presente ... modesta compensación de la ventaja esencial que tienen los historiadores: ellos saben cómo sigue" (Pag. 21)

${ }^{5}$ No queda bien claro, a que se refiere Augé con la corriente culturalista. Puede llegar a dar cierta idea, si uno hace un poco de esfuerzo interpretativo, que se refiere a la escuela del relativismo cultural encabezada por Franz Boas, Bronislaw Malinoswki y Ruth Benedict entre otros.
} 
clara de lo que entiende por modernidad. Tercero y su error capital radica en olvidar la función que juega el rol social dentro de los lugares de tránsito como ser aeropuertos, shoppings, supermercados o carreteras. ¿Cómo se explica la función que juega el rol social dentro de esos espacios? Dudamos, sinceramente, que piensen como "no lugar" a un aeropuerto, aquellos empleados de conocidas líneas aéreas que mantuvieron una huelga y colapsando el sistema comercial aéreo por días y hasta semanas en algunos casos. No creemos, que los argentinos que viven por diversas causas, en el extranjero piensen que el Aeropuerto Internacional de Ezeiza es un lugar sin historia, sin relación y sin espacio. Es más, sería muy posible que este cargado de significado y vivencias para estas personas. Que pensarán aquellos que fueron a recibir a la Selección Argentina de Fútbol al mismo aeropuerto después de su desempeño en el Mundial Alemania 2006, organizado por la Federación Internacional de Fútbol. El concepto de "no lugar" carece, en primera instancia, de sustento empírico; por otro lado, su construcción teorética es totalmente contradictoria. Si en un lugar antropológico hay ubicación geográfica, histórica, y de simbolización, no se puede admitir que su negación se da por la sobresaturación de hechos presentes. Ya que los hechos se dan en una realidad epistemicamente objetiva como ser un aeropuerto o el monte Everest al margen de la interpretación subjetiva. ${ }^{6} \mathrm{El}$ sujeto no da veracidad a la realidad objetiva. Además, parece difícil poder comprender como la antropología puede hacer objeto de investigación algo que ha sido negado, y por ende no puede ser observado como lo es un "no lugar". Excepto, claro está, que se despoje a la antropología de su calidad de disciplina científica.

Por ejemplo, Benjamin Lee Whorf, realizó observaciones que señalaban que los indios Hopi, en los Estados Unidos, dentro de su lengua no manejaban el concepto de "tiempo" y por ende hablarles de futuro, presente y pasado era algo que no estaban preparados para entender. Como así también, Whorf notó, "mediante las formas llamadas aspectos y modos, la gramática hopi también facilita la distinción entre acontecimientos momentáneos, continuos y repetidos, así como la indicación de la secuencia de los acontecimientos sobre los que está informado. Por lo tanto, el universo puede ser descrito sin tener que recurrir a un concepto de tiempo dimensional". (Whorf B, 1971:245). ¿Cómo explicarle a un hopi el concepto de no lugar? ${ }^{7}$ Es que en definitiva, como afirma Jurgen Habemas (1998: 88) "para los integrantes de una misma cultura, los límites de su lenguaje son los límites de su mundo. Pueden dilatar el horizonte de su mundo de la vida tanto como quieran, pero no pueden salirse de él. En este sentido, toda interpretación es también un proceso de asimilación."

\section{UNA DEFINICIÓN DE LUGAR.}

Ante de poder continuar con el desarrollo de este apartado conviene preguntarse ¿que se entiende por definir y bajo que contexto gramatical lo estamos aplicando? Definir, ¿implica usar el lenguaje? ¿uno podría esbozar una definición sin hacer uso del lenguaje?, ¿definir un no lugar aunque más no sea por negación no implica una asimilación cultural?, ¿cuál es el motivo para llamarlo "no lugar"?

\footnotetext{
${ }^{6}$ Véase la definición de John Searle en La Construcción de la Realidad Social. Pág. 28.

7 Esta misma discusión se da entre las más notables corrientes de lingüistas. Por un lado, están aquellos que sostienen que nada puede escaparse al lenguaje, y que todos los hechos sociales que no pueden nombrarse a través de él simplemente no existen; aquí encontramos pensadores de la talla de Sapir y Whorf entre otros. Por el otro lado, Terwillinger y Von Humboldt sostienen que el lenguaje precede al pensamiento y no al revés. En resumen, poder precisar si el pensamiento es anterior o posterior al lenguaje es un tema que ha preocupado a los lingüistas de todos los tiempos, sin que en la actualidad haya arribado a algún tipo de acuerdo.
} 
Berger y Luckmann afirman "la vida cotidiana, por sobre todo, es vida con el lenguaje que comparto con mis semejantes y por medio de él. Por lo tanto, la compresión del lenguaje es esencial para cualquier comprensión de la realidad de la vida cotidiana". (Berger P y Luckmann T,1972: 55). EI punto, entonces radica en saber ¿por qué motivo los hechos deben depender del lenguaje? Según John Searle (1997:80) sólo están ligados al lenguaje aquellos hechos que son "dependientes del lenguaje" tales como esto es un billete de 20 dólares u hoy es martes 13 de Octubre, pero en otros casos, los hechos son independientes del lenguaje, como por ejemplo tener hambre si bien puede implicar una predisposición biológica no es un hecho que dependa del lenguaje. Cuando esa necesidad se institucionaliza, y se le asigna un función el hecho pasa a formar parte del lenguaje y de la realidad socialmente construida.

"La organización del espacio y la constitución de lugares son, en el interior de un mismo grupo social, una de las apuestas y una de las modalidades de las prácticas colectivas e individuales" (Augé M, 1996:57). Una de las formas que tiene el etnólogo de interrogar a la realidad socialmente construida, es a través de tratar el espacio simbólico, ese espacio cargado de significado es "el lugar antropológico". ${ }^{8}$ Continua sobre el tema "estos lugares tienen por lo menos tres rasgos comunes. Se consideran (o los consideran) identificatorios, relacionales e históricos. El plano de la casa, las reglas de residencia, los barrios del pueblo, los altares, las plazas públicas, la delimitación del terruño corresponden para cada uno a un conjunto de posibilidades y de prohibiciones cuyo contenido es a la vez espacial y social" (ibid: 58). En este sentido Augé diría, entonces, que el lugar que nos vio nacer asigna a todos nosotros una identidad particular la cual a la vez se considera simbólica, espacial e histórica. El monumento, es muchas veces, símbolo que se está en presencia de un lugar antropológico. Señala el autor, "el monumento, como lo indica la etimología latina de la palabra, se considera la expresión tangible de la permanencia o, por lo menos, de la duración. Son necesarios altares para los dioses, palacios y tronos para los soberanos para que no sean avasallados por las contingencias temporales. Así admiten pensar la continuidad de las generaciones" (ibid: 65). Los centros de las ciudades y las capitales, son monumentos que otorgan identidad y ejercen un poder institucional sobre quienes forman o residen en ella. Estos centros son unidos y ligados entre sí por un conjunto de conectores, carreteras y pasadores que organizan los itinerarios. "a la entrada de las ciudades, en el espacio triste de los grandes complejos, de las zonas industrializadas y de los supermercados, están plantados los anuncios que nos invitan a visitar los monumentos antiguos. A lo largo de autopistas se multiplican las referencias a las curiosidades locales que deberían retenernos aun cuando estamos de paso, como si la alusión al tiempo y a los lugares antiguos no fuese hoy sino una manera de mentar el espacio presente" (ibid: 79).

El pensamiento de Augé no puede escapar a la reflexión profunda, pero intentaremos focalizar en dos cuestiones ¿qué hechos son necesarios para que se pase de un lugar a un no lugar? y ¿bajo que contextos se deja de pertenecer?

Después de definir un no lugar como un espacio de no identidad, dice el autor "la hipótesis aquí defendida es que la sobremodernidad es productora de no lugares, es decir, de espacios que no son en sí lugares antropológicos y que, contrariamente a la modernidad baudeleriana, no integran los lugares antiguos" (ibid: 83). ¿de que manera la modernidad o mejor dicho la sobremodernidad genera

${ }^{8}$ Dice en forma textual Marc Augé, "el lugar antropológico es de escala variable ... todos son lugares cuyo análisis tiene sentido porque fueron cargados de sentido, y cada nuevo recorrido, cada reiteración ritual refuerza y confirma su necesidad." (Pág. 58). 
no lugares? Dirá el autor, "el hecho de pasar da un estatuto particular a los nombres de lugar, que la falla producida por la ley del otro y donde la mirada se pierde, es el horizonte de todo viaje (suma de lugares, negación del lugar), y que el movimiento que desplaza las líneas y atraviesa los lugares es, por definición, creador de itinerarios, es decir, de palabras y de no lugares" (ibid: 90). Influido notablemente por Michel de Certeau, Augé encuentra en los viajeros, turistas, y en el viaje mismo el elemento central para defender su tesis. Despojado de toda pertenencia histórica, el turista no tiene un vínculo cierto con el lugar que visita y mucho menos con la historia del lugar. Puede durante un tiempo estar contemplando un monumento a los caídos durante la segunda guerra mundial simplemente por curiosidad, sin que ese hecho le remueva nada; es solamente un consumidor. Si bien, la idea de Augé no está muy en desacuerdo con lo que piensan algunos teóricos del turismo, se equivoca cuando le asigna al movimiento o al viaje en sí mismo la capacidad de generar un "no lugar"; sobre todo cuando afirma "el viaje ... construye una relación ficticia entre mirada y paisaje. Y si se llama espacio la práctica de los lugares que define específicamente el viaje, es necesario agregar también que hay espacios donde el individuo se siente como espectador sin que la naturaleza del espectáculo le importe verdaderamente" (ibid:91). No es el desplazarse en sí, lo que rompe con la identidad, prueba de ello son las personas que deben dejar su lugar antropológico de residencia para radicarse en otras partes del mundo tales como los migrantes o los refugiados. Por otro lado, Augé omite contemplar a aquellas personas que cautivadas por el lugar dejaron su pertenencia su status de turista para radicarse en forma definitiva en calidad de ciudadano de ese nuevo lugar.

La rigidez con la que el autor esboza su teoría no permite llegar a buen puerto cuando se comparan sus ideas con los hechos empíricos. Parece empecinado en demostrar que la movilidad atenta contra la identidad y eso no necesariamente deba ser así. Mucho menos, cuando el viaje se institucionaliza dando lugar "al mercado". El turismo, también llamada la industria de los viajes, es una institución social como lo es el mercado; y si se sostiene que el mercado es un lugar ¿porque insistir con que el viaje es su negación? Quizás conviene recalcar, que el turismo genera nuevos lugares de pertenencia acorde al status con el cual el viajero se identifica. Puede afirmarse, incluso, como señala Boullon, que el viajero sostiene una interacción fragmentada, es decir, "el viajero no se considera obligado a continuar una relación con alguien que no coincida con sus gustos y forma de ser ... la relación del turista es una relación fragmentaria, conocen sólo partes de muchas personas en vez de la integridad de unas pocas" (Boullon R, 1986: 106). Es más, Hiernaux, sostiene que las lógicas del trabajo y del ocio nos invitan a comportarnos en formas diferentes. Mientras en la primera la cuestión es el ahorro, en la segunda lo principal es el consumo. (Hiernaux N, 1998:46). En pocas palabras, es el status de turista o trabajador aquel que asigna el grado de pertenencia a un espacio dado y no el movimiento como piensa Augé. Paradójicamente, esa relación no es para nada estática y un turista puede dejar de serlo cuando decide radicarse definitivamente en aquel paraíso que lo cautivó.

A diferencia de Augé, Boullon no concibe el viaje sin el tiempo y entonces afirma "todo viaje incluye los tres momentos en que hemos dividido la constancia del tiempo ... pasado presente, y futuro. El presente es cada instante del tiempo transcurrido, cuando se materializa el viaje. El futuro, desde que se decidió viajar hasta que el viaje se efectúa; abarca buena parte del interés y despierta las ilusiones del viajero ... si alguna vez se regresa al mismo sitio, la experiencia adquiere interesantes singularidades, porque continuamente el viajero ésta confrontando las imágenes elaboradas con la realidad del nuevo presente." (Boullon , 1986:113). Si la apreciación de Boullon es correcta, el viajero no puede desligarse en ningún caso del tiempo y éste lo acompaña hasta su regreso. Sin ese criterio por ejemplo los turistas no retornarían nunca al mismo destino y eso en la realidad no sucede siempre así. 
Además, ya Emmanuel de Kadt se ocupó de demostrar como las relaciones entre turista y residente local no puede escapar a los procesos históricos que subyacen en el encuentro de ambos actores y se repiten tal como fueron en la historia ${ }^{9}$ Tampoco Augé, hace referencia a que clase de tiempo que utiliza cuando habla de "tiempo". ${ }^{10}$

¿Por qué motivo un viaje en el siglo XIX sería diferente en lo que respecta a continuidad histórica comparado con uno en el siglo XX o XXI? Augé dirá, con certeza, la sobremodernidad impone soledad a la multiplicación de los no lugares. Y ya cuando la cosa se pone densa y demasiado rígida, Augé aclara que hay lugares que no existen sino en las palabras que los evocan, algo así como un lugar imaginario. Pero un no lugar, es otra cosa. Ellos si están nombrados por el lenguaje, y en ocasiones señalizados por carteles y leyendas de todo tipo que reglamentan el comportamiento dentro de ellos. El ejemplo más claro es "no transitar a más de 100 kilómetros por hora". ${ }^{11}$ Esas reglamentaciones son las encargadas de mostrarnos los paisajes. "El viajero ya no necesita detenerse e inclusive ni mirar. Así, se le ruega en la autopista del su que preste cierta atención a tal pueblo fortificado del siglo XVIII o a tal viñedo renombrado" (Augé M, 1997:101). Digámoslo de alguna manera una especie de invasión del texto en jurisdicción de los paisajes espaciales reglamentados por el contrato. Sin embargo, su miedo, es que esa relación vacía de sentido por sobrecarga de información. Para comprenderlo mejor, hay que detenerse en el siguiente párrafo "el pasajero de los no lugares sólo encuentra su identidad en el control aduanero, en el peaje o en la caja registradora. Mientras espera, obedece al mismo código que los demás... el espacio del no lugar no crea ni identidad singular ni relación, sino soledad y similitud. Tampoco le da lugar a la historia, eventualmente transformada en elemento de espectáculo, es decir, por lo general, en textos alusivos. Allí reinan la actualidad y la urgencia del momento presente. (Ibid:107)

Como buen etnólogo que es, creemos que Augé se ha tomado el trabajo de observar el tránsito que cualquier día puede notarse en un aeropuerto o estación de trenes. Es cierto, que existe una pauta reglamentada impersonal que todos los pasajeros siguen sin cuestionamiento, pero ello sólo pasa en algunos casos. La génesis de esta tesis radica en comprender como la modernidad con sus excesos provoca una saturación de sentido que lleva a la despersonalización. En cierta forma, una adaptación de la teoría weberiana de racionalización. ${ }^{12}$ Pero con una particularidad, que la distingue de ésta última: la sobrecarga informativa.

En uno de sus pasajes Augé señala "es como si el espacio estuviese atrapado por el tiempo, como si no hubiera otra historia más que las noticias del día o de la víspera, como si cada historia individual

\footnotetext{
${ }^{9}$ De Kadt analiza el turismo y sus efectos en tres destinos tales como Bali, Malta y Chipre. Hemos traído a colación el siguiente pasaje que sintetiza lo que es y la forma en que se dan los encuentros en el turismo entre pobladores locales y visitantes. "La conclusión, aunque difícilmente sencilla, es ciertamente clara a grandes rasgos. El encuentro con los turistas, y especialmente la relación de servicio, se experimente como rebajante y como expresión de servilismo y, por lo tanto, el que provoque hostilidad, depende, al menos en parte, del contexto socio histórico, en especial de los elementos de esclavitud y colonialismo" Véase para más información ¿Turismo Pasaporte el desarrollo? (Pág. 109). 1995. Editorial Endymion

${ }^{10}$ Según las antiguas voces griegas, cuando se habla de tiempo se puede hacer alusión a Cronos o a Kairós. La diferencia radica en que el primero es el tiempo impersonal aquel que nos falta para morir o dicho de otro modo el cronológico, el segundo es el instante en el que se está, por ejemplo un tiempo de felicidad o tristeza sin límites fijos.

${ }^{11}$ En el caso de una carretera o una ruta.

${ }^{12}$ Una de los aspectos a tener en cuenta, es que Augé no mencione en su concepto de sobremodernidad al profesor de Friburgo.
} 
agotara sus motivos, sus palabras y sus imágenes en el stock inagotable de una inacabable historia presente". (ibid: 108). Ese mundo de consumo, crea el narcisismo, la imagen falsa del yo al alcance del bolsillo. Luego, Augé introduce una distinción que le da cierta flexibilidad a su tesis; "en la realidad concreta del mundo de hoy, los lugares y los espacios, los lugares y los no lugares se entrelazan, se interpretan. La posibilidad del no lugar no está nunca ausente en cualquier lugar que sea" (Ibid: 110). Esto trae un problema severo, cuando se trata de comprender y de darle algún tipo de ubicación geográfico espacio-temporal a los no lugares. Es una especie de coartada incontrastable, el afirmar que en cualquier lado donde exista un lugar, puede existir un "no lugar".

¿A que se refiere el autor cuando dice el mundo de hoy?, ¿qué diferencias introduce Augé entre modernidad y sobre-modernidad? En la modernidad el todo se unifica en una gran imagen respetando la diferencia entre lo antiguo y lo novedoso, por el contrario en la sobre-modernidad, lo antiguo se transforma en consumo del presente y se pierde, según el autor "en un espectáculo específico".

Sin embargo, en ninguna parte queda claramente evidenciada cuales son las causas reales que producen la sobre-modernidad. Obviamente, si los "lugares y los no lugares" se entremezclan y se cruzan es difícil poder comparar a un viajero sin identidad, de un nostálgico inmigrante que regresa a ver a su familia después de años de ausencia. Si el anonimato y la relación contractual son los elementos principales para comprender al no lugar y diferenciarlo de lo que es un lugar, entonces por definición las relaciones sociales no deben ser contractuales. El autor, introduce, para explicar esto el ejemplo de una persona que está cómodamente ubicado en su casa, en la cual no tiene que dar muchas indicaciones y es comprendido con facilidad. Pero una vez, que sale al exterior, el asunto cambia y debe utilizar la retórica de su lenguaje para relacionarse con sus pares. Una especie de división entre el lenguaje informal y el formal.

Sin embargo, atribuir al lenguaje informal estrictamente en el ámbito cercano o privado, y al formal en el ámbito público es una arbitrariedad más de las que el autor no puede escapar. Un ejemplo práctico nos lleva al siguiente caso, uno puede escribir una carta a la distancia o enviar un email a un amigo o familiar usando un lenguaje totalmente coloquial, o dar una conferencia en forma verbal en un tono ampliamente formal. Mas aún, la batería de entrevistas que detallaremos a continuación refutan la tesis de Augé en dos sentidos: por un lado, se trata de argentinos que por diversas razones han tenido que emigrar y forma su hogar antropológico en el extranjero, sin embargo sus testimonios son de una gran emotividad, para ellos el aeropuerto Ministro Pistarini tiene una gran significación emotiva cargada de sentido y sobre todo de historia. Por otro lado, y por una cuestión de distancia entre entrevistador y entrevistado, el soporte en el cual se plasmaron las entrevistas fue el texto escrito.

\section{LOS QUE SE FUERON}

Según fuentes informales, se cree que unos 548.013 argentinos residen en el exterior. Entre ellos: unos 150.000 viven en México, 85.230 en Estados Unidos, 72.231 en Israel, 70.224 en España, 58.693 en Brasil, 44.475 en Chile, 20.614 en Italia, 13.546 en Canadá, 10.000 en Francia, 10.000 en Australia, 8.500 en Alemania y 4.500 en Inglaterra. ${ }^{13}$

\footnotetext{
${ }^{13}$ Datos extraídos de La Nación online. Argentinos en el exterior disponible en www.lanacion.com. 17-07-06
} 
De todos ellos, los que a continuación se detallan, son sólo una parte ínfima pero la calidad de sus relatos habla por sí misma.

Carmen tiene cuarenta y seis años, es argentina y actualmente reside en España. Hace nueve años que dejó su país con el fin de mejorar su condición laboral y económica. Cuando vivía en Argentina, se desempeñaba como artista plástica; y le queda pendiente retornar. Aún con la muerte de su padre no ha podido volver. Cuando uno le hace referencia al aeropuerto de Ezeiza, a Carmen le despierta una emoción intensa y sentimientos de angustia. No duda, si se da la oportunidad, de volver a vivir en Argentina pero para ella ese tema es una cuestión pendiente. Aquí viven todos sus seres queridos, madre, hermanos, sobrinos, tíos y primos. ¿Cuál es su lugar antropológico de residencia? ¿Y como comprende Carmen el concepto de No Lugar de Marc Augé?

El caso de Abigail es harto diferente, al de Carmen. Ella tiene 15 años y vive hace unos diez años en España. Sin embargo, a ella la trajeron sus padres a la edad de cinco años. Cuando tiene que describir su vivencia al momento de partir, describe "confusión por su escasa edad", y cuando le preguntamos sobre la posibilidad de retornar al país, respondió "no volvería, porque simplemente no recuerdo casi nada y paso mi adolescencia en España". Abigail tiene tíos y primos viviendo en Argentina.

Ambos testimonios tienen dos lugares diferentes de referencia, para Carmen Argentina para Abigail Europa, sin embargo para ambas el aeropuerto por el cual partieron les da un significado y un sentido a sus recuerdos y a su historia. Los otros dos testimonios, que tenemos reservados son diferentes ya que ambos han vuelto temporalmente de visita a la Argentina.

Javier tiene 28 años, vive en México hace 5 años. El motivo que lo obligó a emigrar fue la crisis financiera de principios de 2002. En ese momento, él trabajaba en una empresa multinacional. Producto de la crisis, la empresa cerró sus oficinas en Buenos Aires, y abrió una filial en México. Javier, quien entonces se desempeñaba como Gerente de Marketing, emigró a México para continuar con su trabajo. Su partida, fue muy difícil y triste. Cuando se le nombra el aeropuerto de Ezeiza, afirma "recuerdo que a mi partida mis familiares fueron a despedirme. No me gustan las despedidas, por lo tanto les pedí que se fueran rápidamente. Recuerdo comer un tostado posterior al PRE embarque, mirando a todos con un dejo de melancolía". A diferencia de los entrevistados anteriores, Javier tuvo la oportunidad de regresar dos veces, la primera a los 6 meses a visitar a sus familiares y la segunda a los 2 años por trabajo. Apenas bajó del avión se le escaparon unas lágrimas y seguido un fuerte olor a gas, típico de Buenos Aires, Javier tiene muy presente aún ese momento. Su primera estadía la recuerda con una gran pena. Según nos dice el entrevistado "la gente estaba muy deprimida, el costo del dólar era un inconveniente, todos estaban muy caídos". En la segunda, ya la cosa había cambiado, disfrutó mucho más de los paseos y de los amigos. Su idea, es volver a vivir en Argentina y dice que el trato de sus compatriotas a sido bueno en las dos ocasiones. Si tuviera que elegir, el prefiere que nadie lo esté esperando cuando llega al aeropuerto. Ahora bien, Javier nos comenta que al poco tiempo de regresar ya quería volverse a México, si bien había planeado quedarse un mes, a las tres semanas adelantó su regreso, el motivo el clima de depresión que reinaba en ese entonces. Las expectativas y las cosas que le pasaban por la cabeza durante su viaje de regreso a México era un tinte de agradecimiento por no vivir en el país.

La historia de Héctor, es diferente aunque el motivo de la migración fue el mismo. El entrevistado tiene 65 años, y hace 5 que vive en España. Héctor era comerciante, presentó quiebra y luego se desempeño como gerente de una mutual hasta el día que decidió partir. ¿el motivo?, no quiso 
perderse la oportunidad probar suerte en otro lugar. Ezeiza para él encierra un sentimiento de pérdida, en el sentido de haber sido estafado en todas las veces que apostó a invertir en el país. Cuando regresó la primera vez, al bajar del avión lo invadió un sentimiento de mucha tristeza. "Se le partió el corazón". Ya con el correr del tiempo, la segunda fue más agradable. Dice Héctor "fue emocionante la primera vez, no tanto la segunda, el tiempo provoca cosas impensables en los afectos. Todo se recuerda como antes, pero nada es igual". Su estadía fue buena, y la recuerda con alegría, los aromas, los gustos y los amigos volvieron a provocarle recuerdos adormecidos. En lo que respecta, a la posibilidad de retornar definitivamente a la Argentina, afirma "es lo que más deseo, supongo que Gardel tenía razón, siempre se vuelve al primer amor. Es donde me crié, me enamoré, me casé, y tuve mi casa, mis hijos, mis amigos, es donde me forjé como ser humano. Mis huesos, mis cenizas estarán ahí. Esto es algo pasajero." Es más, nos comentaba que durante su prime viaje las expectativa eran muchas, el estado de ansiedad era alto, contar sus vivencias en Europa a sus familiares y finalmente un cuestionamiento en lo que respecta a su identidad. Cataloga la experiencia (el viaje) como interesante en lo personal. Nos dice textual "no se sabe exactamente donde uno está parado. ¿A dónde pertenece?, se cuestiona cosas tales como ¿cual es mi lugar?, ¿Qué pasó con mi vida argentina?, ¿Qué estamos haciendo acá en España? Pareciera que algo se rompió dentro, pero según nos comentaban nuestros familiares en Argentina, estábamos más jóvenes más activos."

Los cuatro testimonios apuntan hacia un mismo lugar. Excepto por Abigail, los tres restantes emigraron por voluntad propia. Se asentaron en Europa, construyeron su residencia y establecieron un lugar antropológico al que llamaron su hogar. Sin embargo, ni la modernidad ni la distancia, les pudo hacer olvidar su sentido de pertenencia y de hecho ninguno de los tres duda en regresar si tuviera la opción. Asimismo, para ellos, el aeropuerto que los vio partir, tiene un significado emotivo muy alto y encierra parte de su historia. El caso de Héctor, muestra como se puede pertenecer a dos lugares antropológicos al mismo tiempo, con la confusión que ello implica sin que la distancia o el movimiento deban ser condicionante de ello. Están quienes, olvidan la Argentina apenas pasado 1 año de vivir en el extranjero, pero también hay quienes no pueden hacerlo aun después de vivir más 20 años afuera.

Estos casos empíricos no sólo ponen en jaque la tesis de los "no lugares" como centros productores de anonimato, sino que también cuestionan directamente el núcleo teórico de la tesis que sostiene Augé: que el lugar de residencia debe indefectiblemente ser el lugar antropológico. Por ende, en vistas de lo mencionado, el viaje o el movimiento pueden ser considerados un retorno a la identidad en vez de un espacio de alienación. ${ }^{14}$ Un migrante que regresa temporalmente a lo que alguna vez fue su pasado como en el caso de Héctor y Javier, vuelve por la carretera, por el aeropuerto o por el tren a reencontrarse con su identidad. La tesis de Augé debe ser invertida y reformulada de manera que pueda adaptarse a los hechos observables.

Por otro lado, también encontramos a los que nunca se fueron, que continúan viviendo en el país y que de los aeropuertos o la industria turística hacen su entorno laboral. De ellos, nos ocuparemos a continuación, son la otra cara de la moneda.

\footnotetext{
${ }^{14}$ Aunque Marc Augé no utilice la palabra “alienación” sino anonimato.
} 


\section{LAS HUELGAS AEROPORTUARIAS}

"En relación a las normas, reglamentaciones y otro tipo de procedimientos formales. Igual que una descripción del trabajo puede ser usada por un empleado para definir lo que no está preparado para hacer, las normas y reglamentos suelen demostrar que son de doble filo. Encontramos un destacado ejemplo en el caso de British Rail, donde los empleados han descubierto el poder del trabajo a reglamento. Mejor que ir a la huelga para conseguir una reivindicación o solucionar algún agravio, un proceso que demuestra ser costoso para los empleados debido a que pierden su sueldo, el sindicato suele declarar una huelga de celo, por lo que los empleados hacen exactamente lo que es requerido por los reglamentos desarrollados por las autoridades ferroviarias". (Morgan G, 1995:151)

El siguiente texto, fue escrito, hace un tiempo por el consultor Gareth Morgan, cuando se dispuso analizar las relaciones de poder en el trabajo. En efecto, en nuestro medio laboral se dan un sinnúmero de situaciones y relaciones a las que pueden denominarse sociales. Una huelga, un paro, una negociación o la iniciación del trabajo a reglamento presuponen un conflicto de intereses entre dos partes. Ese conflicto, es una forma de relación y está enraizado en la historia del lugar físico en el que se suscita. La pregunta para un trabajador aeroportuario en huelga sería ¿qué significado tiene un aeropuerto o una estación de trenes para un piloto de avión o un conductor?, ¿puede llamarse "no lugar" a lo que un maquinista considerará su lugar de trabajo?, ¿el concepto de lugar y "no lugar" no depende del sujeto y su función de status?, ¿son los aeropuertos un lugar de protesta?

Hemos realizado una recopilación de casos, en los que se tomaron Aeropuertos y otros cetros turísticos en forma simbólica, como medida de protesta a la situación laboral que experimentaban los trabajadores de esos centros.

El 09 de Marzo de 2006, el diario Clarín reportaba "un reclamo salarial de empleados de carga y descarga de valijas paralizó el aeropuerto desde temprano. Hubo 32 vuelos retrasados; algunos, de más de 10 hora. Otros fueron cancelados". ${ }^{15}$ Miles de personas, quedaron varadas como consecuencia de esta medida. Los pasajeros, repudiaron el paro mediante un silbido generalizado. Algunos tuvieron que permanecer en el aeropuerto internacional de Ezeiza por más de seis horas. Por ejemplo Fransico de 82 años, tuvo que esperar el vuelo de Alitalia, compañía que lo llevaría a reencontrarse con sus familiares en Roma. La causa que generó la huelga, según el secretario del gremio aeroportuario, fue el incumplimiento por parte de Intercargo de un aumento de \$250 prometidos hace tiempo atrás.

El día 10 de Marzo de 2006, Pagina 12, encabezó sus titulares "volvieron al paro los pilotos y técnicos de Aerolíneas Argentinas". Por idéntica situación que el paro de los maleteros, el conflicto fue provocado por reclamos salariales. ${ }^{16}$ Otro reclamo salarial, llevará a los pilotos de Lan Chile a considerar la posibilidad de otro paro, en julio de $2006 .{ }^{17}$

\footnotetext{
15 Informe publicado en diario Clarín a cargo de Vivian Urfeig el 09-03-2006. Artículo disponible en www.clarin.com. Extraído el 17-07-2006. "Ezeiza, largas demoras y miles de pasajeros afectados por un paro".

${ }^{16}$ Informe publicado en diario Pagina 12, a cargo de Fernando Krakowiak el 10-03-2006. Artículo disponible en www.pagina12.com. Extraído el 17-07-2006. "Volvieron al paro los pilotos y técnicos de Aerolíneas Argentinas".

17 Informe publicado en el Diario de Cuyo el 13-06-2006. Artículo disponible en www.diarioelcuyo.com. Extraído el 17-07-2006.
} 
Ahora, si se piensa que esto es sólo en Argentina, se está muy equivocado. En todas partes del mundo, se han declarado huelgas similares. En Estados Unidos, por ejemplo, en 1985 hubo una huelga generalizada en las principales cadenas hoteleras de New York que hizo perder al turismo 16 millones de dólares. ${ }^{18}$ Por lo general, una de las características que tienen este tipo de paros es que son llevadas a cabo en plena temporada de ocupación, lo cual provoca más daño a los propietarios de las compañías e innumerables trastornos a los pasajeros o clientes. Por ese motivo, muchas veces, se llega a un acuerdo entre las partes antes que se tome la medida. ${ }^{19}$ En otros casos, hay medidas que generan daños considerables a la Industria, como la huelga que provocó en Nepal una pérdida de 50 billones de rupias tras un paro general de empleados hoteleros. ${ }^{20}$

Desde el punto de vista de la tesis de los no lugares, ¿como se pueden asimilar estos hechos? Vale decir, pueden distinguirse cuatro actores en cuestión, los trabajadores, los pasajeros, los empresarios y el Estado. ¿Qué significación tiene un aeropuerto para cada uno de ellos? Una respuesta tentativa sería: para los empresarios su lugar de producción tal como una fábrica o un negocio, para los trabajadores su lugar de protesta, para los pasajeros un lugar de tránsito que se transforma en un lugar de espera, para el Estado un espacio público que debe ser liberado mediante mecanismos de disuasión o represión. ${ }^{21}$

\section{LO CERCANO Y LO LEJANO - discusión filosófica.}

Los casos descriptos aportan cierta evidencia que contradicen la tesis de los "no lugares" y sus implicancias teóricas. No obstante, ¿que diría Marc Augé a estos argumentos?, sin lugar a dudas, dirá que bajo situación de conflicto o huelga, "el contrato", elemento fundamental que hace de sí mismo un no lugar, pierde su validez. Por ende, un aeropuerto puede pasar de ser un "no lugar" en situaciones donde el equilibrio a convertirse en su negación en aquellas en las que impere en conflicto. De todos modos, el autor no ha tenido en cuenta esa salvedad y su respuesta a la pregunta planteada no deja de ser una mera especulación personal. Ahora bien, Augé nada aclara de que pasaría si ese contrato impersonal sobre el cual se afirma el "no lugar" se quiebra. Olvida quizás las palabras de Simmel cuando afirma "La historia entera de la sociedad podría reconstruirse a partir de la lucha, el compromiso, las conciliaciones lentamente conseguidas y rápidamente desbaratadas que surgen entre la tendencia a fundirnos con nuestro grupo social y a destacar fuera de él nuestra individualidad" (Simmel G, 2002:42). En toda relación social pueden observarse dos procesos inevitables e inseparables: la cooperación y el conflicto.

\footnotetext{
18 Informe publicado en New York Times a cargo de Robin Toner el 04-08-1985. Artículo disponible en www.newyorktimes.com. Extraído el 17-07-2006. "Tourism recovers after hotel strike".

19 Informe publicado en Washington Post a cargo de Neil Irwin el 07-01-2005. Artículo disponible en www.washingtonpost.com. Extraído el 17-07-2006. "Hotel Union threatens to strike before inauguration".

20 Informe publicado en People's Daily On line el 27-04-2006. Artículo disponible en www.peoplesdailyonline.com. Extraído el 17-07-2006. "Tourism industry losses billons of rupees due to strike in Nepal.

${ }^{21}$ Entiéndase mecanismos de represión al uso coercitivo de la fuerza para desalojar a los manifestantes, y como mecanismos de disuasión a la intervención que hace el Estado en las negociaciones entre empresarios y trabajadores. Por ejemplo, ante la toma de un Aeropuerto, el Estado está facultado para dictar el inmediato desalojo si los manifestantes no presentaron los requisitos que pide el Ministerio de Trabajo o una conciliación obligatoria, en la que llama a ambas partes a iniciar negociaciones.
} 
La otra cuestión, la relación espacial, nos lleva a preguntarnos. ¿Desde que punto de comparación resuelve Augé la diferencia entre lo lejano y lo cercano?, ¿Qué es lejos y que es cerca y según que y quienes? Si esa misma relación se lleva al campo temporal, se podría decir que el ahora es lo cercano y el pasado lo lejano, si es correcta esta apreciación, ¿que vínculo le da Augé con la modernidad? En forma textual, exponemos "es, pues, con una figura del exceso - el exceso de tiempo - con lo que definiremos primero la situación de sobre modernidad, sugiriendo que, por el hecho mismo de sus contradicciones, ésta ofrece un magnifico terreno de observación" (Augé M, 1997:36).

Sin embargo, la modernidad es creada cuando la idea de algo nuevo recibe como resistencia a la idea de tradición. Algo que me permite diferenciarme de lo nuevo pero a su vez poder comprenderlo. Tuvo que haber una edad media, para que existiera una edad moderna. "Intentamos ahora distinguir nuestra modernidad de la de los otros, de quienes, antes que nosotros se declararon modernos" (Ricoeur P., 2004: 404). Por se motivo, es imposible pensar el presente, aislado del pasado y concebir al no lugar como sobrecargado de presente que le permite escapar del pasado y de la historia. Por un lado quien haya leído a los clásicos de fines de siglo XIX, notará que la preocupación ante el avance de los que ellos denominaban "la modernidad" no era muy diferente a los pensadores de finales del XX. Por el otro cabe señalar (aunque parezca reiterativo) que el presente puede tomar diversas formas, y Augé desconoce que incluso puede ser olvidado, pero a la vez recordado.

Si el concepto de tiempo encierra, según la definición, lo que es aquí y lo que no lo es. Entonces, el exceso de presente llevaría al olvido, algo que no se ubica ni en el pasado ni en el futuro pero que puede volver al presente con sólo evocarlo. Más precisamente debido a que olvidamos es que recordamos, y a través la capacidad de estar ausente es que puede devenir un recuerdo del pasado, si todas las imágenes estuvieran en presente no existiría rememoración, y para ello es necesario el olvido. En otras palabras, es imposible entender el recuerdo sin el olvido.

El olvido es aquel que hace posible la memoria, por lo menos así lo entendía también Heidegger cuando afirmaba "sí como la espera de algo sólo es posible sobre la base de estar a la espera, de igual modo el recuerdo "erinnerung" sólo es posible sobre la base del olvidar, y no al revés; porque en la modalidad del olvido, el haber sido abre primariamente el horizonte, en el que comprendiéndose, el Dasein perdido la exterioridad puede acordarse de lo que se preocupa" (Heidegger en Ricoeur,2004: 566). Citando, al mismo Heidegger, comprendernos como seres en lo cercano y a los otros en lo lejano parece ser una contradicción ya que el fin del ser ahí en el mundo es la muerte. El fundamento existencial del "ser ahí" es la temporalidad. La temporalidad del "ser ahí" desarrolla el contar el tiempo. El tránsito al ya no ser, la muerte de los otros, saca al ser ahí de la posibilidad de experimentarse por sí mismo. En el morir de los otros puede experimentarse el fenómeno del ser como vuelco en que un ente pasa de la forma del "ser ahí" al ya "no ser ahí". En el dolorido pensar en ella son los supervivientes con ella de un modo de procurar por que tributa honras. La perdida que se experimenta con la muerte, los supervivientes. La totalidad del ser ahí es constituida por el acabarse. "el ente que somos antológicamente nosotros mismos es lo más lejano" (Heidegger M,1951: 358). ${ }^{22}$

Desde un punto de vista práctico, retomamos el caso de los que han tenido que emigrar; si recuerdo les está dado por la negación o mejo dicho, por el olvido. Recuerdan, su país con más fuerza porque ya no viven en él; ansían su regreso aunque sea por no más de una semana, por la razón de que

\footnotetext{
${ }^{22}$ Si en algo coinciden Ricoeur y Heidegger, dos posturas por demás antagónicas, es que el recuerdo sólo puede recordarse a través de haber sido olvidado previamente. Es decir que si no existiese el olvido no existiría el recuerdo.
} 
saben que deben volver. Conciben lo lejano como muy cercano precisamente justo allí donde el mismo recuerdo surge como causa de la distancia. Sin embargo, si regresarán a vivir a la Argentina, esa añoranza se diluiría. Dirían, estos dos grandes filósofos contemporáneos, es precisamente en la lejanía que se está cerca y paradójicamente en la cercanía es que muchas veces el ser se encuentra lejos. ${ }^{23}$

\section{EL CONTRATO}

La otra pieza fundamental en el pensamiento de Augé para analizar el "no lugar", es el contrato. ¿Qué uso le da a este elemento el autor? "como los lugares antropológicos crean lo social orgánico, los no lugares crean la contractualidad solitaria. ¿Cómo imaginar el análisis durkheiminiano de una sala de espera de Roissy? (Augé M., 1997:98). Este párrafo trae consigo todo el sentido que el autor, la da al contrato como productor de "no lugares" y reflejo del proceso de sobremodernidad.

Si bien, su lectura del pensamiento de Durkheim con respecto a la solidaridad mecánica y al contractualismo de las sociedades, pueda ser correcto. Se equivoca, cuando atribuye al sociólogo francés la idea de que la sociedad "contractualista" deba ser solitaria. Durkheim advierte "Los sentimientos colectivos devienen, pues, cada vez más impotentes para contener las tendencias centrífugas que fatalmente engendra la división del trabajo, pues de una parte, esas tendencias aumentan a medida que el trabajo se divide, $y$, al mismo tiempo, los sentimientos colectivos mismos se debilitan" (Durkheim E, 2004:361).

¿Pero donde encuentra el autor para controlar los efectos anómicos de la división del trabajo?, la respuesta es en las normas y el contrato que de ellas se deriva. El siguiente pasaje es evidentemente claro con respecto a ello, "las sociedades superiores no pueden mantenerse en equilibrio como el trabajo no se halle dividido; la atracción del semejante por el semejante cada vez vale menos para producir ese efecto" (ibid:394) ... "el derecho y la moral tal es el conjunto de los lazos que nos obligan unos a otros y a la sociedad, y que hacen de la masa de los individuos un agregado, uno y coherente. (ibid:395) ... si la división del trabajo produce solidaridad, no es sólo porque haga de cada individuo un factor de permuta, como dicen los economistas, es que crea entre los hombres todo un sistema de derechos y deberes que los liga unos a otros de una manera durable. De la misma manera que las semejanzas sociales dan origen a un derecho y a una moral que las protegen, la división del trabajo da origen a reglas que aseguran el concurso pacífico y regular de las funciones divididas" (ibid:402).

En ningún momento, Durkheim atribuye a la especialización la causa última de la despersonalización y la solidaridad. Durkheim seguramente a la pregunta de Augé, respondería en una sala de espera de Roissy la solidaridad existe de la misma manera que una tribu primitiva, sólo que cada uno interactúa en la medida que su función social así se lo establezca, y si entre ellos no se comunican, no es por anomia sino todo lo contrario por una normativa basada en la solidaridad orgánica que establece como innecesario que dos personas desconocidas establezcan una relación en una sala de espera

\footnotetext{
${ }^{23}$ El testimonio de Héctor es elocuente al respecto cuando señala "fue emocionante la primera vez, no tanto la segunda, el tiempo provoca cosas impensables en los afectos. Todo se recuerda como antes, pero nada es igual".
} 
fuera de cualquier relación comercial. Como esa misma norma establece que el empleado de la aerolínea le exija al pasajero su billete antes de abordar. ${ }^{24}$

En resumen, concluimos señalando, que la lectura de Augé sobre Durkheim no sólo es errónea, sino también sesgada con un tinte subjetivo que intenta atribuir al sociólogo francés un argumento que nunca sostuvo.

\section{EL TURISMO Y SU NORMATIVA}

Hasta aquí hemos sido un poco injustos con Augé; si algo hay que reconocer es que su descripción de los lugares de tránsito no es tan alejada de la realidad. Quien alguna vez haya estado en un aeropuerto o un supermercado entenderá el motivo por el cual Augé señala "pero los no lugares reales de la sobremodernidad, los que tomamos cuando transitamos por la autopista, hacemos las compras en el supermercado o esperamos en un aeropuerto el próximo vuelo para Londres o Marsella, tienen de particular que se definen también por las palabras o los textos que nos proponen: su modo de empleo, en suma, que se expresa según los casos de modo prescriptivo - tomar el carril a la derecha, prohibitivo - prohibido fumar- o informativo - usted entra en el Beaujolais. (Augé M, 1997:100). Sin embargo, no puede precisar el tiempo en el cual surge la sobremodernidad; este hecho provoca que no pueda dársele un corte más o menos aproximado a la génesis de la sobremodernidad. En otras palabras, ¿Cuándo empieza la sobremodernidad?, ¿es el turismo un fenómeno que deriva de ella? Es curioso, que Augé tampoco tome una definición conceptual del turismo. ¿a quienes se considera turistas?, ¿Qué diferencia existe entre un turista y un viajero?

La Organización Mundial de Turismo define como tal a "toda actividad de individuos que viajan y permanecen en lugares fuera de su ámbito de residencia por motivos de ocio, negocios $u$ otros propósitos por más de 24 horas pero menos de 1 año". En estos términos, un argentino residente en España por más de cuatro años entra en la categoría de turista cuando regresa temporalmente a visitar familiares en la ciudad de Buenos Aires. Sin embargo, es cuestionable y muy difícil de dilucidar si el lugar antropológico de este supuesto turista es Madrid, donde actualmente reside o Buenos Aires donde subyace su historia. Sin dudas, Augé diría "Buenos Aires no ha dejado de ser su lugar antropológico", lo cual lleva a otra dificultad: ¿Por qué afirmar que la sobremodernidad y dentro de ella el turismo no identifica a los individuos? El autor, tiene una respuesta para esa pregunta; " $E I$ espacio de la sobremodernidad está trabajado por esta contradicción: sólo tiene que ver con individuos (clientes, pasajeros, usuarios, oyentes) pero no están identificados (nombre, profesión, lugar de nacimiento, domicilio) más que a la entrada o a la salida" (Augé M, 1997: 114). Una vez más, Augé sólo toma el caso del viajero y descarta a quienes hacen del turismo su trabajo o profesión: al comenzar un vuelo el capitán del avión saluda a su tripulación dice su nombre y apellido para ser identificado, los empleados del aeropuerto tienen señalizados su apellido y el cargo que desempeñan para ser ubicados fácilmente.

Por otro lado según el derecho internacional privado, todo individuo debe ser juzgado dentro de la jurisdicción donde se cometió el delito al margen de su nacionalidad. Es decir, que un robo en un aeropuerto francés por parte de un turista argentino será sometido a los tribunales ordinarios de la justicia francesa, bajo el código francés. Desde el punto de vista jurídico, al gozar de sus deberes y

\footnotetext{
${ }^{24}$ En Simmel se encuentra una tesis similar a la de Durkheim. Véase Sobre la Aventura (Pág. 317-361).
} 
derechos un turista, es tan imputable como cualquier otro. Augé parece darse cuenta de lo mismo y dice "cuando un vuelo internacional sobrevuela Arabia Saudita, la azafata anuncia que durante ese período quedará prohibido el consumo de alcohol en el avión. Así se significa la intrusión del territorio en el espacio. Tierra = sociedad = nación = cultura = religión: la ecuación del lugar antropológico se reinscribe fugazmente en el espacio." (ibid:119)

Sin embargo, no es el único caso en que el viajero está sujeto a reglamentación. Cuando se sucede un motín o algún tipo de disturbio durante el viaje, según el código aeronáutico argentino, se dispone que el capitán ejerza el poder de policía y si es necesario encarcele temporalmente a quienes causan ese disturbio a fin de restablecer el orden dentro de la aeronave. ${ }^{25}$ Si por deducción, existe una norma reglamentada y un órgano capaz de ejercer el uso coercitivo para hacer respetar esa normativa, puede afirmarse sin temor a equivocarse que el viajero o turista está sujeto a derechos y deberes; y si esto es así, parece un tanto apresurado hablar de un "no lugar antropológico", al margen del territorio. Los mismos deberes y derechos a los cuales se circunscribe cuando celebra un contrato con la Aerolínea que lo transporta. ¿Es correcto llamar a un lugar, no lugar cuando quienes forman parte de él están sujetos a la misma normativa de quienes no son parte? Esta idea contradice los conceptos básicos de la antropología, sobre los cuales Bronislaw Malinowski señala "en todas partes hallamos un lugar, un grupo, un conjunto de normas, reglas de técnica, un estatuto y una función ... Un análisis más profundo mostraría, además, que en cada caso tenemos un fundamento muy claro y definido en el estudio del ambiente material, con los objetos específicos que le pertenecen, como los edificios, el equipo y el capital incorporado a una institución ... las normas constitutivas representan la idea de institución, tal como es concebida por sus miembros y definida por la comunidad" (Malinowski B, 1967:61-62)

En el año 1961, el sociólogo alemán Hans Paul Bahrdt escribe un ensayo analizando las influencias de la Moderna Metropoli. Al igual que Augé, Barhdt pensaba el mundo social en dos sentidos: una vida pública donde los individuos interactúan reglados por las normas y la formalidad y una vida privada donde el contacto se da en forma más completa e intima. El pasaje de la esfera pública a la privada se da por elección del sujeto. Su preocupación es como la vivienda, desde el punto de vista sociológico y arquitectónico se transforma a través del tiempo. En uno de sus pasajes, el autor afirma "Es interesante destacar que las deficiencias técnicas del damero ya fueron señaladas antes de la motorización. Pero los absurdos que surgen en la actualidad de esta forma edilicia no pueden solucionarse por medios de generosos ensanches en las calles, construcción de túneles y habilitación de playas de estacionamiento, pues su origen está en el propio sistema. Este pierde sentido en el momento en que la calle no es transitada solamente por peatones y a veces por carros a caballo sino que ha caído bajo el dominio de los veloces automóviles. (Bahrdt H,1970:132)

Sin dudas, Bahrdt está preocupado en que el proceso de construcción relegue a la naturaleza hasta el punto en que provoque una des-urbanización por auto repliegue. ¿Qué soluciones plantea Bahrdt

\footnotetext{
${ }^{25}$ El código aeronáutico argentino está formado por 236 artículos. Entró en vigencia derogando las leyes 13.345, 14.307 y 17.118 y los decretos ley $1.256 / 57$ y $6.817 / 63$. Sancionado por ley 17.285 (1967). En su capítulo XI titulado "abandono de Aeronaves" Título V "Personal Aeronáutico" artículo 81 se establece "El comandante de la aeronave tiene, durante el viaje, poder de disciplina sobre la tripulación y de autoridad sobre los pasajeros. Debe velar por la seguridad de los mismos, no pudiendo ausentarse de la aeronave sin tomar las medidas correspondientes para su seguridad". Nota 81: se agrega durante el viaje para precisar el sentido de la norma. Conc.: Ley 14.307, art. 76; proy. 1958, art. 71. El mismo cuerpo, en el artículo 86 dice "El comandante de la aeronave tiene el derecho de arrojar, durante el vuelo, las mercancías o equipajes si lo considera indispensable para la seguridad de la aeronave."
} 
al respecto? Dice en forma textual "no sólo por motivos de índole arquitectónica sino también por razones de orden sociológico debe iniciarse la planificación de una unidad urbana en la habitación aislada de una vivienda privada ... para que un cuarto pueda albergar la existencia privada del hombre debe tener un tamaño y una forma determinada (pág151)...Aun en los momentos de auge de la construcción, la mayoría de los compradores deben contentarse con lo que le ofrecen y tienen pocas posibilidades de modificar la oferta mediante la selección ... nada parece más sencillo que preguntar a la gente si requiere una vivienda propia, una cocina con office o si necesitan dos ambientes o tres (pág. 152).

Lo cierto es que para que se emita un billete aéreo, debe existir un compromiso entre dos partes que acuerdan celebrar y respetar un contrato el cual queda sujeto a una normativa, como lo es por ejemplo El Convenio de Varsovia; que en su artículo número tres estipula "en el transporte de viajeros el porteador está obligado a expedir un billete de pasaje, que deberá contener las indicaciones siguientes: a) Lugar y Fecha de emisión, b) puntos de partida y de destino, c) las paradas previstas, bajo reserva de la facultad para el porteador de estipular que podrá modificarlas en caso de necesidad, y sin que dicha modificación pueda hacer perder al transporte su carácter internacional, d) el nombre y la dirección del porteador o de los porteadores, e) indicación de que el transporte está sometido al régimen de responsabilidad establecido por el presente convenio." Este convenio fue sancionado en el año 1929 y entra en vigencia en 1933.

Particularmente, en el turismo, quien alguna vez haya estado en un hotel (como señala Bahrdt), dará razon que sus habitaciones dobles, simples, triples y suites parecen decoradas en forma idéntica e impersonal. Su diseño, arquitectura y decoración no respeta la individualidad de sus clientes sino por el contrario los masifica de acuerdo a estándares normativos prefijados. Algunos pensarán que este hecho es un ejemplo más de producción industrial capitalista a escala. Otros, un exceso de reglamentación en la vida del hombre que provoca su despersonalización. A lo segundo, es a lo que apunta Marc Augé; y ciertamente algo de razón tiene, no obstante esas reglamentaciones son las que permiten la interacción y el equilibrio entre las partes intervinientes. La construcción y la arquitectura de un hotel están reguladas por la Ley de Hotelería Nro. 18.828 cuya sanción se dio en el año 1970. En la misma, se establece respetar ciertos parámetros prefijados tanto en las habitaciones como otros ambientes según la calificación del establecimiento, sea éste 1 o 5 estrellas, fijando límites de acuerdo también a la cantidad de pisos con los que conste la construcción. Dentro de esta normativa entran todos los hoteles catalogados como "turísticos". ${ }^{25}$

En cierta manera, es muy difícil atribuir a la sobre modernidad la facultad de influir en leyes sancionadas hace más de veinte años, sobre todo cuando el mismo autor no da ningún dato que indique en que año o década comienza y termina la sobre modernidad. Por lo demás, es insuficiente y en cierto modo infantil pensar que la norma en conjunción con el espacio histórico dan origen a un lugar, y esa misma norma asociada a un aeropuerto, un shopping, un hotel $u$ otro lugar de consumo produzcan un "no lugar".

\footnotetext{
${ }^{25}$ El artículo uno de la ley nacional 18.828 dice "El presidente de la Nación Argentina sanciona y promulga con Fuerza de ley: Los establecimientos comerciales en zonas turísticas o comprendidos en planes nacionales de promoción del turismo y los que por sus características el organismo de aplicación declare de interés para el turista, que ofrezcan normalmente hospedaje o alojamiento en habitaciones amuebladas por períodos no menores al de una pernoctación, a personas que no constituyan su domicilio permanente en ellos, quedan sujetos a la presente Ley y a las normas que se dicten en su consecuencia, sin perjuicio de las reglamentaciones locales en cuanto no se les opongan".
} 


\section{LAS CONSULTAS, LOS RECLAMOS Y LAS SANCIONES}

En la obra "Los No lugares" no se hace mención alguna a aquellos casos en los que el viajero, el consumidor o el turista están disconformes con el servicio recibido. Al ser un viaje un bien intangible, las posibilidades de no cubrir las expectativas subjetivas del viajero son grandes. El reclamo, las inquietudes, al igual que el conflicto son sucesos que nos permite de alguna manera continuar ligados al lugar donde se originó ese reclamo: sus causas, permiten por otro lado medir el grado de vinculación del individuo hacia esa institución. Si las normativas vigentes cumplen su función, si los órganos existentes dan lugar a esos reclamos se produce otro hecho institucional: la sanción. No es posible, ahora, extenderse más sobre los conceptos de sanción pero sobre ella podemos afirmar que nos mantiene dentro de los límites: ¿es posible que un "no lugar" tenga sanciones y reclamos?

En Augé, eso no está muy claro. Si un viaje se considera como un lugar de tránsito de no relación, ¿Cómo considerar al reclamo parte del viaje? En efecto, el reclamo no sólo que es parte del viaje, sino que también indicador necesario de relación y de historia: nos mantenemos psíquicamente unidos al pasado a través de él. En Argentina según datos suministrados por el Instituto Nacional de Estadística y Censo, en el año 2002 se presentaron a la Dirección de defensa al consumidor un total de 84.099 consultas. Los motivos y los rubros eran variados; unas 15.202 por facturación, 3.403 garantía, 26.614 mala prestación del servicio, 549 falta de energía, 1.112 publicidad engañosa, 503 formas de venta, 2.725 falta de información, 1.152 riesgos para la salud, 3.231 aumento de precios, 17.919 por Ley 25.561, y otros 1.689.

Dividido así en tres rubros: Servicios privados con 49.617 y servicios públicos con 17.494, y Productos con 16.988 inquietudes. Claramente, los servicios privados son aquellos que mayor cantidad de consultas generan. Dentro de esa división se encuentra el turismo. De un total de 1.678 consultas recibidas: 885 por mala prestación del servicio, 512 por facturación, 103 por falta de información, y 175 otros. Sin embargo, si se los compara con otros rubros tenemos la siguiente tabla.

CUADRO No. 1

Consultas realizadas a la Dirección de Defensa al consumidor, sólo Servicios por Rubro. Año 2002.

Elaboración Propia.

\begin{tabular}{lr} 
Servicios & Totales \\
Total de Servicios Privados & \\
Corralito & 9.530 \\
Tarjetas de Crédito & 5.809 \\
Otros & 4.502 \\
Créditos Bancarios & 4.260 \\
Medicina Prepaga & 4.206 \\
Seguros & 3.544 \\
Telefonía Celular & 3.459 \\
TV por Cable & 2.698 \\
Bonos nacionales y provinciales & 2.187 \\
Inmobiliarios & 1.685 \\
Turismo & $\mathbf{1 . 6 7 8}$ \\
Cerramiento toldos & 1.115 \\
Colegios & 1.098 \\
Internet & 946 \\
Reparaciones en Gral. & 827 \\
Tintorerías y Lavaderos & 826 \\
Cajeros Automáticos & 491 \\
Tiempo compartido & 345 \\
Servicios Bancarios & 201 \\
\hline
\end{tabular}




Consorcios 164

Créditos privados 44

Fuente: Ministerio de la Producción. Secretaria de la Competencia, la Desregulación y la Defensa al Consumidor. Dirección de Defensa al Consumidor.

Puede observarse, que el turismo se ubica en la mitad de la tabla incluso con más consultas en comparación a otros rubros como colegios, Internet y tiempo compartido. Eso habla de cierto vínculo de los consumidores para con la actividad.

De esa manera, es inexplicable que haya tantas consultas en un ámbito donde no existe vínculo relacional alguno mucho menos una relación histórica. De todos modos replicaría Augé, las consultas no implican más relación y de ninguna manera suponen que ésta se transforme en un reclamo o en una sanción normativa. Para el caso, una consulta a la Dirección de Defensa al Consumidor no es muy diferente de una realizada en un mostrador de American Airlines sobre los costos de un viaje Buenos Aires - New York. Ella no implica relación entre el potencial viajero y el empleado de la aerolínea. El vínculo es más bien contractual y totalmente impersonal, carente de identidad y sentido al igual que aquel que se da cuando un consumidor plantea una inquietud en una organización de defensa al consumidor.

Llegado a este punto, cabe entonces reflexionar no sobre las consultas en sí mismas, sino en ellas cuando se transforman en un reclamo puntual, sobre todo cuando expresan insatisfacción por el servicio recibido. Desde el momento en que un reclamo o un litigio implican una respuesta de una de las partes involucradas es un error afirmar que no exista entre ellas ningún tipo de vínculo. Un caso análogo al de la huelga al cual ya hemos hecho mención.

Si profundizamos más en el tema, y observamos un historial de los reclamos presentados en el rubro turismo desde 1998 a 2002 dentro de los servicios privados podríamos llegar a resultados más interesantes que una mera especulación teórica.

CUADRO No. 2

Reclamos presentados ante los tribunales Arbítrales de consumos nacionales. Año 1998-2002.

Elaboración propia. Sólo servicios privados.

\begin{tabular}{lllllll} 
Rubro & \multicolumn{7}{l}{ Cantidad de Reclamos presentados } \\
& Totales & 1998 & 1999 & 2000 & 2001 & 2002 \\
Bancarios & 1.396 & 84 & 222 & 105 & 215 & 770 \\
Otros & 918 & 86 & 196 & 162 & 360 & 114 \\
Tarjetas de Crédito & 486 & 47 & 132 & 78 & 108 & 121 \\
Medicina prepaga & 372 & 53 & 131 & 86 & 74 & 28 \\
Reparaciones en General & 218 & 44 & 56 & 24 & 67 & 27 \\
Planes de capacitación y ahorro & 208 & 0 & 0 & 0 & 0 & 208 \\
Financieras & 190 & 42 & 81 & 15 & 30 & 22 \\
Turismo & $\mathbf{1 8 4}$ & $\mathbf{1 9}$ & $\mathbf{3 5}$ & $\mathbf{2 4}$ & $\mathbf{8 5}$ & $\mathbf{2 1}$ \\
Seguros & 172 & 18 & 50 & 18 & 54 & 32 \\
Inmobiliarias & 131 & 38 & 31 & 17 & 37 & 8 \\
Cursos de capacitación & 53 & 9 & 18 & 6 & 16 & 4 \\
Cerramientos & 52 & 20 & 16 & 1 & 2 & 13 \\
Internet & 30 & 0 & 0 & 3 & 0 & 27 \\
Limpieza y similares & 24 & 21 & 10 & 0 & 0 & 3 \\
Gestoría & 3 & 2 & 0 & 1 & 0 & 0 \\
Colegios & 3 & 1 & 1 & 1 & 0 & 0
\end{tabular}

Fuente: Ministerio de la Producción. Secretaria de la Competencia, la Desregulación y la Defensa al 
Consumidor. Dirección de Defensa al Consumidor.

La tendencia muestra a los Bancos, las tarjetas de crédito, la medicina prepaga y las reparaciones en general como las principales actividades en donde se presentaron mayor cantidad de reclamos efectivos. El turismo, dentro de los servicios, se ubica en el octavo lugar seguido inmediatamente de los seguros, las inmobiliarias y los cursos de capacitación. Entre el año 2000 y 2001 la cantidad de reclamos se duplica, salta de 24 a 85 respectivamente para luego volver al nivel anterior. Esa misma tendencia puede notarse en la mayoría de los rubros con excepciones de: la medicina prepaga, los colegios, la Internet y la gestoría. Debido a la crisis financiera que experimentara Argentina a fines de 2001 la cantidad de reclamos en rubro bancario casi se triplica para 2002, ¿a que resultados pueden llegarse con estos datos? El reclamo tiene una conexión directa con el uso, a mayor uso mayor posibilidad de reclamos. Debido a la sensibilidad del Turismo como actividad comercial a los procesos de desequilibrio y conflicto la cantidad de personas que dispusieron de sus vacaciones para viajar fue menor que años anteriores. Por el contrario, rubros como Planes de capacitación y ahorro o Bancario por las restricciones financieras, tarjetas de crédito e Internet como mecanismo para explorar sobre las posibilidades de emigrar, vieron acrecentado notablemente su uso. Por ende, la cantidad de reclamos entre 2001 y 2002 no hace más que seguir aumentando en ellos. Esto demuestra, que el reclamo es una forma de vínculo social muy activo que une y no que se retrae.

CUADRO No. 3

Sanciones aplicadas por infracciones a la ley de Lealtad Comercial por rubro. 2002 Elaboración propia. En pesos.

\begin{tabular}{|c|c|c|c|}
\hline Motivo & Bancos & $\begin{array}{l}\text { Rubros } \\
\text { Telefonía }\end{array}$ & Turismo \\
\hline Totales por motivos & $\$ 17.000$ & $\$ 50.000$ & $\$ 24.300$ \\
\hline Falta o incorrecta exhibición de precios & $0 \$$ & $5.000 \$ 2.300$ & \\
\hline Publicidad engañosa. & $\$ 17.000$ & $\$ 45.000$ & $\$ 22.000$ \\
\hline
\end{tabular}

Fuente: Ministerio de la Producción. Secretaria de la Competencia, la Desregulación y la Defensa al Consumidor. Dirección de Defensa al Consumidor.

El cuadro número tres, se refiere a las sanciones expresadas en pesos argentinos de sólo tres rubros dedicados a los servicios privados: Bancos, Telefonía y Turismo. La sanción, por otra parte, implica un castigo por violar una normativa. Por tratarse de servicios intangibles, sus principales motivos son la mala exhibición de tarifas y la publicidad engañosa. En este punto, hay que darle cierto crédito a Marc Augé cuando afirma "La mediación que establece el vínculo de los individuos con su entorno en el espacio del no lugar pasa por las palabras, hasta por los textos. Sabemos ante todo que hay palabras que hacen imagen o más bien imágenes (Augé M, 1997:98). Cuando el individuo cae en la realidad, esa imagen contrasta con lo efímero y prueba de ello es que de las sanciones aplicadas a las empresas turísticas la mayor parte sean por motivos de publicidad engañosa, al igual que la telefonía cuya consecuencia está supeditada a la sobre-modernidad. Todo esto, que ha sido expuesto, juega a favor de las tesis del "no lugar". Sin embargo, esta conclusión es algo engañosa ya que si todo quedaría debidamente explicitado como dice el autor, no debería haber sanciones de este tipo. ${ }^{26}$ Cabe darle al autor solamente en este caso el beneficio de la duda.

\footnotetext{
${ }^{26}$ En la página número 107, Augé advierte "como los no lugares se recorren, se miden en unidades de tiempo. Los itinerarios no se realizan sin horarios, sin tableros de llegada o de partida que siempre dan lugar a la
} 


\section{LA TENDENCIA (una discusión final)}

"En sus modalidades más limitadas, al igual que en sus expresiones más exuberantes, la experiencia del no lugar (indisociable de una percepción más o menos clara de la aceleración de la historia y del achicamiento del planeta) es hoy un componente esencial de toda existencia social. De allí el carácter muy peculiar y en total paradójico de lo que se considera a veces Occidente como el modo de replegarse sobre sí mismo... a partir de allí son concebibles todas las actitudes individuales: la huida (a su casa, a otra parte), el miedo (de sí mismo, de los demás), pero también la intensidad de la experiencia (la performance) o la rebelión (contra los valores establecidos). Ya no hay análisis social que pueda prescindir de los individuos, ni análisis de los individuos que pueda ignorar los espacios por donde ellos transitan... en el anonimato del no lugar es donde se experimenta solitariamente la comunidad de los destinos humanos. Habrá, pues, lugar mañana, hay ya quizá lugar hoy, a pesar de la contradicción aparente de los términos, para una etnología de la soledad". (Augé M, 1997:122123). ¿Cómo puede traducirse este alegato final?

En primer lugar, Augé parece hablar de una tendencia o por lo menos parece haber cierto tono que indica eso. ¿Pero una tendencia hacia donde?, por un lado el individuo parece replegarse cada vez más en su esfera privada, en si mismo, a la defensiva. Por el otro, a la espera de revelarse contra los valores de la sobre-modernidad anclados en el consumo, la soledad y el anonimato. Una especie de solipsismo que sería característico de las sociedades occidentales. En esta última parte del trabajo, nos dedicaremos a desmenuzar este intrincado rompecabezas y para hacerlo más divertido nos hemos servido de algunos datos que extrajimos del turismo en Argentina y en España. (con los cuales podremos echar algo de luz a nuestro problema).

Que el turismo o la industria de los viajes están creciendo en todo el mundo no es ninguna novedad. Tampoco lo es el hecho de que los cambios tecnológicos hayan disminuido notablemente el tiempo de viaje desde el siglo XVII al siglo XXI. Hoy día, un viaje de Madrid a Buenos Aires nos lleva entre 8 y 12 horas en avión cuando en el siglo XIX con suerte dos semanas en barco. Pero esta tendencia, no se da para todos por igual. Si bien, los cambios tecnológicos han aumentado el tiempo libre, existe una correlación muy marcada entre nivel socioeconómico y tendencia a consumir turismo. Aquí entonces, cabe señalar lo que es un viaje a corta distancia quizás obligado por el trabajo y lo que representa un viaje de placer o vacaciones.

Los roles, como ya lo hemos mencionado, son diferentes. Aunque tengan sus similitudes no es lo mismo un emigrante, un turista, y un piloto de avión. Aún cuando los tres se desplazan, diferentes son sus roles y ergo diferentes serán sus formas de comportarse e interactuar con los demás, ésta es la primera distinción importante que Augé ha omitido en todo su trabajo. Ahora bien, en España por ejemplo se realizaron en 2003 un total de 129.2 millones de viajes con al menos una pernoctación; sin embargo el $65.3 \%$ representaban viajes de corta duración, y sólo el 34.7\% eran turísticos. No sólo el

mención de posibles retrasos. Se viven en el presente. Presente del recorrido, que se materializan hoy en los vuelos transcontinentales sobre una pantalla donde se registra a cada minuto el movimiento del aparato. Si es necesario, el comandante de a bordo lo explica de manera un tanto redundante: a la derecha del avión pueden ver la ciudad de Lisboa. De hecho no se percibe nada: el espectáculo, una vez más, sólo es una idea, una palabra. En la autopista hay carteles luminosos que dan la temperatura del momento y las informaciones útiles para las practicas del espacio“. Sin embargo, parece paradójico que ante tanta saturación de información las principales sanciones en la actividad turística están alrededor de la publicidad engañosa y la no exhibición de los precios. De todos modos dice Augé "Esta superabundancia espacial funciona como un engaño, pero un engaño cuyo manipulador sería muy difícil de identificar (no hay nadie detrás del espejismo)" (pág. 39). 
turista puede ser considerado viajero, pero Augé no define este concepto sino que lo deja a la deriva. En lo que respecta al nivel educacional, el $70.8 \%$ de los que ha viajado por placer o turismo posee estudios superiores, ese porcentaje comienza a declinar considerablemente hasta llegar al $26.2 \%$ en la población analfabeta. Y aquí Augé comete otro error grosero, la mayoría de los que viaja lo hace en transporte privado como ser su propio coche $(76.5 \%)$, sólo una minoría viaja en autobús $(9.8 \%)$, avión (6.6\%), tren (5.4\%) y barco (1.1\%).

Con respecto a los viajes en general ¿Quiénes viajan más?, según el informe la clase política es la que más viaja (79.8\%) por lo menos hasta una vez en 2003 , luego intelectuales y profesionales (75\%), y técnicos o profesionales de apoyo (68\%), mientras que aquellos que menos viajes hacen son los obreros no calificados $(40 \%) .{ }^{27}$ Atendiendo a la población según situación laboral, la población que más viaja es la económicamente ocupada (53.7\%), contra un $35.7 \%$ de parados o desocupados. La tendencia muestra que a mayor nivel educativo y posición socio económica mayor probabilidad a desplazarse.

Por último, volviendo a los viajes por turismo, el principal motivo es el viaje a campos o playas con un $57.6 \%$, le siguen el turismo cultural $15.5 \%$ y de otros tipos $23.5 \%$. Según la forma de organizarse esos viajes, muy pocos son los que aprovechas las bondades de los adelantos tecnológicos en Internet para reservar sus pasajes ( $82.4 \%$ no usa), sólo el $10.5 \%$ usa esta herramienta y el restante $7.1 \%$ no sabe o no responde. Si han de volver o no, las cifras son muy claras sobre ello; la mayoría de los turista repite su visita (77.1\%) mientras que una minoría no lo hace (19.2\%) y el resto no sabe (3.7\%). ${ }^{28}$ Si la tendencia es volver, eso habla de un innegable vínculo no sólo con el destino sino también con su población que une el pasado, con el presente y el futuro. En resumen, los datos empíricos muestran un notable contraste en lo que a tendencia se refiere según lo expuesto en Marc Augé. Si los no lugares han de proliferar o no, parece que esto no deba ser necesariamente por causa del turismo o la industria de lo viajes. En la actualidad, son los turistas mismos quienes en forma activa emprenden y organizan sus viajes estableciendo una serie de contactos y vínculos sin intermediarios de la agencia de viajes. Sin ir más lejos, el siguiente cuadro estadístico de elaboración propia, muestra como comparativamente entre 2004 y 2005 disminuye el porcentaje de aquellos que organizan sus viajes con agencias idóneas y proporcionalmente sube el porcentaje de los que lo hacen por cuenta de terceros. Las tendencias son similares tanto para quienes vienen como para quienes se van:

CUADRO NRO. 4

Modalidad de Organización de viaje. (Elaboración propia)

\begin{tabular}{|c|c|c|c|c|c|}
\hline \multirow[t]{3}{*}{ Origen } & \multicolumn{3}{|c|}{$\begin{array}{l}\text { TURISMO RECEPTIVO } \\
\text { Modalidad de organización de viaje }\end{array}$} & \multirow{3}{*}{$\begin{array}{l}\text { Por Agencia } \\
\text { de turismo }\end{array}$} & \multirow{3}{*}{$\begin{array}{l}\text { Por cuenta } \\
\text { de Terceros. }\end{array}$} \\
\hline & \multirow{2}{*}{ Totales } & Con paquete & Por cuenta & & \\
\hline & & Turístico & Propia & & \\
\hline Año 2005 & 1.786 .712 & 599317 (33.54\%) & 476311 (26.65\%) & 316614 (17.72\%) & 394470 (22.07\%) \\
\hline Año 2004 & 1.508 .868 & 430911 (28.55\%) & 498292 (33.02\%) & $382740(25.36 \%)$ & 196925 (13.5\%) \\
\hline \multirow[t]{2}{*}{ Origen } & \multicolumn{3}{|c|}{$\begin{array}{c}\text { TURISMO EMISIVO } \\
\text { Modalidad de organización de viaje }\end{array}$} & \multirow[b]{2}{*}{ Por Agencia } & \multirow[b]{2}{*}{ Por cuenta } \\
\hline & Totales & Con paquete & Por cuenta & & \\
\hline
\end{tabular}




\begin{tabular}{|c|c|c|c|c|c|}
\hline & & Turístico & Propia & de turismo & de Terceros. \\
\hline Año 2005 & 1.124 .360 & 166835 (14.83\%) & 241435 (21.47\%) & 195038 (17.34\%) & 521052 (46.34\%) \\
\hline Año 2004 & 1.005 .232 & 117915 (11.73\%) & 315935 (31.42\%) & 307571 (30.59\%) & 263811 (26.24\%)- \\
\hline
\end{tabular}

Fuente: Indec-SECTUR. Encuesta de turismo internacional. Secretaría de Turismo de la Nación.

Las cifras de visitantes aumenta de un año para otro, pero también la posibilidad de arreglar los viajes por cuenta de terceros relegando cada vez más a las omnipresentes agencias de viajes y turismo. Es posible, que exista una tendencia a asegurar con una reserva previa al alojamiento pero usando de intermediarios a familiares, conocidos o amigos. En este punto, se encuentra otro error conceptual por parte del autor. Si el individuo presenta una tendencia a recluirse por miedo, sobresaturación de la información u otras causas, es de fácil deducción que aumente proporcionalmente la intensidad de sus vínculos personales. En pocas palabras, el miedo a lo desconocido nos aferra a lo que es conocido. Tal como lo había explicado Emile Durkheim, en el Suicidio, a mayor hostilidad ambiental mayor será la cohesión grupal y por ende la acción profiláctica hacia el suicidio. (Durkheim,b2004:163).

En esta misma línea de pensamiento ¿bajo que argumentos supone Marc Augé que se tienda hacia una inevitable soledad e individualidad? Este es otro de los tantos problemas que el autor no ha tenido en cuenta. Su concepción del mundo moderno, o sobre-moderno usando sus propios términos, parece cargado de un determinismo que contradice sus valoraciones subjetivas. Si bien por un lado, la sobre-modernidad parece una fuerza inexpugnable que somete a los individuos a su voluntad, y que los aleja cada vez más del entorno social, ¿por qué motivo darle un tinte valorativo a tal movimiento? Este problema en Marc Augé, no es muy diferente en otros pensadores contemporáneos. El dilema es entonces, como entender el determinismo sin emitir juicios valorativos. Quien mejor ha podido analizar este tema fue Isaiah Berlín (2004:23) quien advierte "en otras palabras, lo que pretendo no es más que hacer explícito lo que no ponen en duda la mayoría de los hombres que no es racional creer que las decisiones son causadas $y$, al mismo tiempo, considerar que los hombres son merecedores de reproches o indignación (o sus contrarios) por decidir obrar, o dejar de obrar como deciden". En efecto, quizás la sobre-modernidad deba ser comprendida dentro del contexto en la cual se desarrolla sin que por ello se deba presuponer que traiga consigo consecuencias nefastas. Que los hombres estuvieran sometidos a las fuerzas homogeneizantes e impersonales de la modernidad era una preocupación que ya la tenían pensadores como Stuart Mill por ejemplo.

En Chateaubriand los lugares sagrados a los cuales hace referencia en su viaje a Jerusalén, cumple cierta cercanía con el concepto que él pretende imponer de los no lugares que salen publicados en folletos y revistas de actualidad. Pero olvida, Augé que para comprender a este pensador hay, que primero, adentrarse en el contexto socio-histórico de la época. Lo mismo puede decirse de su confusión del misticismo de Michel de Certeau y su concepto de religioso de lugar; concepto que en nada puede compararse con el de "no lugar", de Marc Augé. La cuestión para Rene de Chateaubriand parecía ser similar. En una cita que Augé (pág.95) toma dice "aquí siento perplejidad. ¿debía ofrecer la pintura exacta de los lugares santos? Pero entonces no puedo sino repetir lo que se ha dicho antes de mí: nunca quizás un tema fue menos conocido por los lectores modernos, y sin embargo nunca un tema fue completamente agotado. ¿debo omitir la descripción de esos lugares sagrados? Pero ¿no será eso quitar la parte más esencial de mi viaje? Y hacer desaparecer lo que es su fin y su objeto". Para Augé estos lugares santos tenían cierta similitud con los no lugares. Entonces, ¿no es totalmente contradictorio afirmar que entonces los no lugares deben ser un 
producto de la sobremodernidad? Sin embargo, ese no es el punto. El pensamiento de Francois René Vizconde de Chateaubriand es otro; su preocupación se halla en la reivindicación del cristianismo por sobre las demás religiones y el avance de la modernidad; los lugares sagrados eran sólo una forma de resaltar la erudición del cristianismo frente a otras formas religiosas. Augé entonces entiende (Pág. 95) que "entonces, describe con aplicación, hace alarde de erudición, cita páginas enteras de viajeros o de poetas como Milton o el Tasso. Esquiva, y es segura esta vez aquí la abundancia de palabras y de documentos que permitirían definir los lugares santos de Chateaubriand como un no lugar muy próximo al de nuestros folletos. " En su obra Viaje a América, Chateaubriand define (sin rodeos) en la introducción la importancia que tienen los viajes en la historia de los hombres, de la cual se extrajo el siguiente pasaje "Ios viajes son una de las fuentes de la historia, pues por medio de las narraciones de los viajeros se hermana la historia particular de cada país con la de las naciones extrañas. Los viajes se remontan hasta la cuna de la sociedad, y los libros de Moisés nos cuentan las primeras emigraciones de los hombres. En estos libros vemos al patriarca conducir sus ganados en las llanuras de Canaán, al árabe vagar por sus solidarias arenas, y al fenicio explorar los mares". (Chateaubriand R. F, 1944:13).

No obstante cabe aclarar que el concepto de viaje del autor está relacionado con los expediciones conquistadoras que en nada tiene que ver con el sentido que pretende darle Marc Augé. La modernidad trae consigo una disminución en los viajes exploratorios si se lo compara con la época en la que escribe Chateaubriand; las facilidades tecnológicas ya no hacían de las expediciones de los antiguos una aventura; sin embargo esa no es la preocupación central del autor, para él a diferencia de otros pensadores contemporáneos, la modernidad trae consigo una idea de progreso al cual el hombre y sobre todo el cristianismo no debe dar la espalda. Su pensamiento, más allá de lo que piensan sus críticos no es para nada conservador. No existe en las ideas de Chateaubriand pesimismo sobre la modernidad; por ende es complicado citarlo como predecesor teórico o respaldo a la tesis de los no lugares. Finalizando su concepto sobre los viajes, el pensador ,francés del siglo XIX, se pregunta "¿conviene que las comunicaciones entre los hombres se hayan hecho tan fáciles? ¿las naciones no conservarán mejor su carácter peculiar ignorándose las unas a las otras, y guardando una fidelidad religiosa a las costumbres y tradiciones de sus padres? Yo he oído en mi juventud murmurar a los viejos bretones contra los caminos que se quería abrir en sus bosques, cuando aquellos caminos debían elevar el valor de las propiedades riberiegas ... los gustos y la admiración del hombre estacionario emanan de juicios falsos sobre la verdad de los hechos y la naturaleza del hombre; sobre la verdad de los hechos, porque supone que las antiguas costumbres morales eran más puras que las modernas; lo que es un completo error; y sobre la naturaleza del hombre, porque no quiere ver que el espíritu del hombre es susceptible de perfección". (Chateaubriand R, 1944:64).

Una vez más, como lo hizo con el profesor Durkheim, Augé manipula o pretende poner en Chateaubriand una idea que este nunca pensó, por lo cual la aproximación de Augé a la literatura de la época sea una vez más totalmente falaz. Además, no es posible interpretar la complejidad del pensamiento de estos clásicos franceses con sólo leer una obra. Por lo general es recomendable internarse en toda la batería de ensayos e investigaciones que han escrito tanto Chateaubriand como Durkheim, por lo menos si se quiere reflejar con objetividad sus principales tesis.

Sin embargo, aquí surge un tema que es conveniente aclarar. Un lugar sagrado (antropológico) tiene similitudes a cualquier otra clase de lugares, pero sólo la posibilidad de llevar "un nombre" le da su carácter de tal; al igual que una escuela, un pueblo, una ciudad o una tribu de Indonesia. No es la 
posibilidad de rendir culto a los dioses lo que hace antropológico un lugar sino la posibilidad de ser nombrado y aprehendido por la cultura. Al igual que una Catedral o una ciudad, el aeropuerto posee un nombre que lo distingue no sólo de otros aeropuertos sino también que lo afirma dentro de la cultura local y le da su lugar en la historia. No existe aeropuerto en el mundo que esté desprovisto de su nombre. Por ejemplo, el aeropuerto Internacional de Ezeiza ha sido bautizado "Ministro Pistarini" o el aeropuerto domestico de la ciudad "Jorge Newbery", así como el internacional de Chicago ha sido llamado "O'Hare International" o el de Madrid "Barajas", otros llevan el nombre de sus propios países o regiones, como el de Bangkok o Barcelona. Lo cierto es que ninguno puede escapar al nombre que su cultura y su idioma le han impuesto. Asumir, pues, que un aeropuerto por considerarse un "no lugar" es implícitamente señalar que deja de ser parte de la cultura que lo ha creado. Lo cual, simplemente parece ser un disparate y contradice la mayoría de la bibliografía seria en antropología cultural.

Augé, no sólo debe revisar nuevamente todos los elementos analíticos que utiliza en su trabajo sino que también debe vincularlos, relacionaros y compararlos empíricamente. Preguntarse por ejemplo, ¿que dirán los arqueólogos, sociólogos y antropólogos del año 3500 cuando descubran enterrados tres metros bajo tierra los folletos turísticos sobre Cancún impresos en el 2006? O ¿Qué diría la arqueología de nuestra sociedad actual cuando interprete esos folletos? ¿Seremos catalogados como homo-consumers o como homo-politicus?

Al margen de cómo seremos recordados por la posteridad ¿puede uno precisar que diferencia hay entre un aeropuerto sofisticado construido en siglo XXI y una destacamento español del año 1600?; es muy posible que la respuesta sea ninguna. ${ }^{31}$ En todo lugar donde exista un nombre, un trabajo y por tanto la posibilidad de construir una cultura hay un indicio de que estamos en presencia de un "lugar antropológico". Sin embargo, ese lugar y esa percepción es subjetiva de quien o quienes hacen posesión de ese lugar. Las necesidades que tuvo Juan de Garay en las ciudades que fundó no fueron las mismas que aquellas que tuvieron los indios que fueron desplazados y des-alojados.

Al respecto, traemos ante el tribunal como testigo a Diego Rodríguez de Valdés y Vanda quien en el año 1599 le escribía una carta su majestad el rey Felipe III. Veinte años después de la fundación de Buenos Aires (Ilamada de la Trinidad por ese entonces) por Juan de Garay, la cuidad presentaba un panorama desolador. En el enunciado de las carencias que percibía el militar español queda evidentemente claro lo que para él representaba debía tener un lugar "al presente en esta ciudad no hay vino, para decir misa, ni cera, ni aceite, para alumbrar al Santísimo Sacramento, ni tafétan, ni otra seda, ni holanda, ni otro lienzo para poder hace lo necesario para el servicio de los altares y ornato del culto divino, ni hierro, ni acero para el servicio de las piezas de artillería y arcabuces que hay en este puerto; ni hierro para las rejas de los arados y hoces para cegar el trigo, ni hachas para cortar leña y labrar madera, ni para poder hacer un azadón para cavar la tierra, ni para poder hacer una tapia; no cordobán, ni otro género de que poder hacer unas calzas; ni lienzo para camisas, ni holanda, ni ruán para cuellos, ni jabón para lavar la ropa, ni ningún género de paños para vestirse; y es tanto extremo que no se halla en esta ciudad cintas para unos zapatos y generalmente faltan todas las cosas necesarias para el sustento y el vestir del hombre, excepto trigo y maíz, ha de venir a faltar totalmente si no hay, como se va acabando, los materiales de hierro y acero para cultivar la tierra y segar el dicho pan." La carta fue fechada 20 de mayo de 1599. (Deleis M y otros,2001:43). Hoy día, a

\footnotetext{
${ }^{31}$ el apaisado es nuestro.
} 
excepción del tinte religioso, esta carta histórica no es muy diferente a la queja de un turista cuando advierte que el aeropuerto está desprovisto de negocios donde comprar, lugares donde comer, o baños donde lavarse los dientes. La misma necesidad que lleva a los empleados aeroportuarios a la huelga cuando reclaman una mejora en sus condiciones laborales, es la que llevó a Rodríguez de Valdés y Vanda peticionar al rey por los elementos necesarios para cegar el trigo. En el siglo XVI era una carta lacrada, hoy a través de un email o un libro de quejas.

En resumen, podemos afirmar que la tesis antropológica sobre los "no lugares" carece de un sustento empírico y por lo demás está sujeta a numerosas especulaciones que la alejan considerablemente de la realidad social que pretende describir. En ningún momento, el autor intenta cuestionarse sobre el hecho de que lo que piensa que está frente a sus ojos fuese real. Esa postura intenta a través de la manipulación de autores de renombre como Durkheim, de Certau o Chateaubriand, imponer una línea de pensamiento que se acerca más a la ideología que a la observación científica.

De todos modos, y a pesar de las limitaciones que han sido expuestas, el concepto de "no lugar" está presente en todo tipo de trabajos, investigaciones y simposios tanto de las disciplinas sociales como sociología, antropología, filosofía y ciencias de la comunicación. Ha prendido también en la literatura periodística como un concepto "comodín", se usa para elaborar sentencias informativas pero por sí mismo su significado no tiene sentido alguno. Utilizado por aquellos que describen el destierro de los que deben marcharse al extranjero hasta los que se ocupan de los más variados temas como cortes de ruta, pobreza, niños de la calle, piqueteros y exclusión social. Muchos a la hora de nombrar un camino, una ruta, o una estación de trenes dicen estar frente a un "no lugar". Otros más originales, intentan reflejar el concepto a través del arte. ${ }^{29} \mathrm{O}$ en congresos o simposios celebrados en prestigiosas universidades. ${ }^{30}$

¿Cómo precisar cuando y como fue que este falso concepto hizo su aparición en los medios visuales y escritos argentinos. Quizás, responder esa pregunta pueda no ser parte de está investigación, pero ser la antesala para quien desee continuarla. ${ }^{31}$

${ }^{29}$ Dice Silvia Attwood "si un lugar puede definirse como sitio de identidad -de memoria- un no lugar es precisamente lo opuesto: un espacio específico, de tránsito veloz, que homologa y quita identidad a sus usuarios, volviéndolos seres anónimos, con poca o escasa intercomunicación. ¿Qué sucede si en ese no lugar, previsible y rutinario, inserto un elemento ajeno, extraño e impertinente? Mi propósito es provocar un cambio en el estatus del no lugar; convertir por unos días este espacio público en un tráfico de palabras y sensaciones que permitan olvidar por unos instantes la soledad y el silencio, que un No lugar transmute por acción de la gente y el arte en un lugar". Lo expuesto, es una invitación a una exposición audiovisual en el centro cultural Borges, en la ciudad de Buenos Aires. Publicado en www.ccborges.org.ar. Extraído el 20-07-2006.

${ }^{30}$ El 12 de mayo de 2005 se llevó a cabo en la Facultad de Filosofía y Letras de la Universidad de Buenos Aires un taller titulado "Desplazamientos, contactos y lugares". En el mismo había muchos geógrafos, sociólogos, antropólogos, entre otros. Uno de los asistentes, Jorge Gobbi publicaba un comentario crítico a cerca de los términos que aún siguen usándose en esta clase de eventos, los no lugares estaban dentro de ese glosario. Dice Gobbi "en general, me parece que el resultado del congreso es bueno, porque además me sirvió para ver un cierto estado, aún un poco caótico, de los estudios sociales sobre el viaje y el turismo. Es así: me sigue llamando la atención el hecho de que conceptos de una pobreza conceptual atroz, como los "no lugares" o "el simulacro", se siguen usando en un campo de estudios que se presupone debería ser crítico con los términos que se usan para describir lo real". Javier, además es profesor docente de la UBA. Está a cargo del seminario "comunicación, viajes y representaciones sociales" que se dicta en la carrera de Ciencias de la Comunicación, y es además jefe de trabajos prácticos de la materia Teoría y práctica de la Comunicación II. Es secretario de redacción de la revista de etnología para Pymes, Expand IT, y colabora en la revista Users, ambas de MP Ediciones.

${ }^{31}$ En el psicoanálisis tampoco podía faltar el concepto de los no lugares. Belen Gache en el libro Lazos de Familia, compilado en 2004 por Ana Amado y Nora Dominguez afirmaba "en escenarios urbanos, suele denominarse a los niños pobres o abandonados chicos de la calle. Esta denominación se refiere a una existencia 
Este humilde ensayo es una respuesta a esa clase de sociología teleológica que en aras de señalar lo que es correcto y lo que no, cae en un dogmatismo que la hace simplemente ininteligible y peligrosa. En definitiva, aún no queda muy claro que es un "no lugar" y cuando darse cuenta que se está frente a uno. Por cierto es, que esa es la mayor fortaleza de esta clase de trabajos y al mismo tiempo su mayor debilidad.

\section{Referencias}

Augé, Marc (1996). Los No Lugares: espacios del anonimato. Barcelona: Gedisa.

Bahrdt, Hans Paul (1961). La moderna metrópoli. Buenos Aires: Editorial Universitaria de Buenos Aires. 1970

Berger, Peter y Luckmann, Thomas. (1965). La Construcción de la realidad social. Buenos Aires: Amorrortu Editores, 1972

Berlin, Isaiah. (1988). Cuatro ensayos sobre la libertad. Madrid: Editorial Alianza.

Boullon, Roberto C. (1986). Las actividades turísticas recreacionales. México D.F.: Trillas.

Chateubriand, René François de. (1826). Viaje a América. Buenos Aires: Emecé Editores, 1944.

Deleis, Monica, de Titto, Ricardo y Arguidenguy, Diego. (2001). Cartas que hicieron la historia.. Buenos Aires: Aguilar.

Durkheim, Émile. (1893). La división social del trabajo.. Buenos Aires: Ediciones Libertador, 2004.

Durkheim, Émile. (1897). El suicidio. Buenos Aires: Gorla, 2004.

Habermas, Jurgen. (1981). Teoría de la acción comunicativa I: racionalidad de la acción social y racionalización social. Bogotá: Taurus Humanidades, 1998.

Heidegger, Martin. (1927). El ser y el tiempo. Ciudad de México: Fondo de Cultura Económica, 1951.

Hiernaux, Nicolás. (1996). Elementos para un análisis socio-demográfico del turismo. Revista Universitaria de Geografía. Vol. 5(2).

Kadt de, Emmanuel. (1995). Turismo ¿pasaporte al desarrollo? Perspectivas sobre los efectos sociales y culturales del turismo en los países en vías de desarrollo. Madrid: Endymion.

Malinowski, Bronislaw. (1948). Una teoría científica de la cultura. Buenos Aires: Editorial Sudamericana, 1967.

Morgan, Gareth. (1995) Images of organization. Londres: Sage.

en donde prima por un lado, el deambular y por el otro el total interperio y falta de cobijo. Este constante deambular por espacios públicos, extraños y ajenos, que no llevan para él marca de pertenencia ninguna, justifica el decir que estos niños transitan por no lugares. Esta no pertenencia a ningún lugar, han sido desalojados o, en todo caso, colocados en un lugar negativo de rechazo". JUANITO LAGUNA Y EL PENSAMIENTO NOMADE, 2004. 
Ricoeur, Paul. (2000). La memoria, La historia, el olvido. Buenos Aires: Fondo de Cultura Económica de Argentina, 2004.

Searle, John. (1995). La construcción de la realidad social. Barcelona: Paidós, 1997.

Simmel, Georg. (2002). Sobre la aventura: ensayos de estética. Barcelona: Península.

Whorf Lee, Benjamin. (1956). Lenguaje, pensamiento y realidad. Barcelona: Barral Editores, 1971.

\section{Formato de citación}

Korstanje, Maxi. (2006). El viaje: un crítica al concepto de "no lugares". Athenea Digital, 10, 211-238. Disponible en http://antalya.uab.es/athenea/num9/KorstanjeM.pdf.

Este texto está protegido por una licencia Creative Commons.
Usted es libre de copiar, distribuir y comunicar públicamente la obra bajo las
siguientes condiciones:
Reconocimiento: Debe reconocer y citar al autor original.
No comercial. No puede utilizar esta obra para fines comerciales.
Sin obras derivadas. No se puede alterar, transformar, o generar una obra
derivada a partir de esta obra.
$\underline{\text { Resumen de licencia }}$
$\underline{\text { Texto completo de la licencia }}$

